BANCA D'ITALIA

E U R O S I S T E M A

Questioni di Economia e Finanza

(Occasional Papers)

Euro Area (cross-border?) banking

by Pierluigi Bologna and Marianna Caccavaio 

13 BANCA D'ITALIA

E U ROS I S T E M A

\section{Questioni di Economia e Finanza}

(Occasional papers)

Euro Area (cross-border?) banking

by Pierluigi Bologna and Marianna Caccavaio

Number 228 - September 2014 
The series Occasional Papers presents studies and documents on issues pertaining to the institutional tasks of the Bank of Italy and the Eurosystem. The Occasional Papers appear alongside the Working Papers series which are specifically aimed at providing original contributions to economic research.

The Occasional Papers include studies conducted within the Bank of Italy, sometimes in cooperation with the Eurosystem or other institutions. The views expressed in the studies are those of the authors and do not involve the responsibility of the institutions to which they belong.

The series is available online at www.bancaditalia.it .

ISSN $1972-6627$ (print)

ISSN 1972-6643 (online)

Printed by the Printing and Publishing Division of the Bank of Italy 


\title{
EURO AREA (CROSS-BORDER?) BANKING
}

\author{
by Pierluigi Bologna and Marianna Caccavaio*
}

\begin{abstract}
This paper presents stylized facts of the segmentation of the Euro Area (EA) banking system and investigates cross-border banking dynamics. Results show that the determinants of cross-border banking change substantially over-time: (i) in the pre-crisis period of financial integration the physical distance and the financial distance between countries were the main drivers; (ii) during the global financial crisis banks reduced the concentration in their foreign claims portfolio and retrenched from the more externally vulnerable countries but kept on investing in the still profitable countries with a sound fiscal position; and (iii) during the EA sovereign tensions, while portfolio diversification and the pull-back from externally vulnerable countries continued, foreign claims were also driven by the deteriorating sovereign conditions, the bank-sovereign link, and opportunities for flight-to-quality. During the crisis the structure of banks' international organization also mattered as banks retrench more when they do not operate through foreign branches and subsidiaries.
\end{abstract}

JEL Classification: F36; G01; G21

Keywords: Euro Area; Cross-border banking; Foreign claims; Financial stability.

\section{Contents}

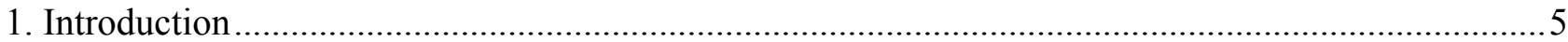

2. Fragmentation of the EA banking and financial system: stylized facts .......................................... 6

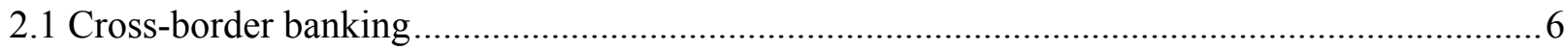

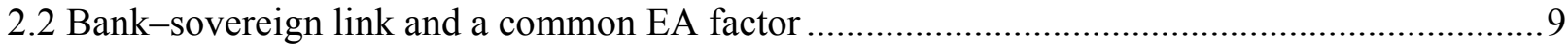

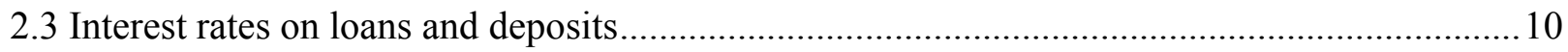

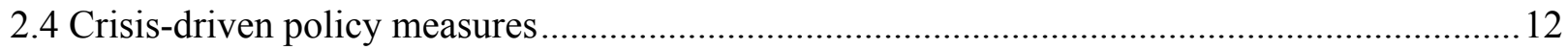

3. The dynamics of EA cross-border banking: an empirical assessment............................................. 13

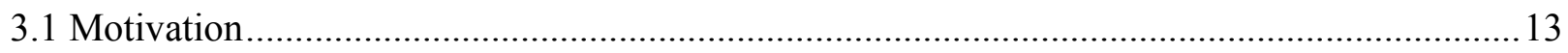

3.2 A conceptual framework for EA cross-border banking ...................................................... 14

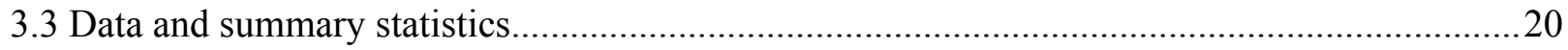

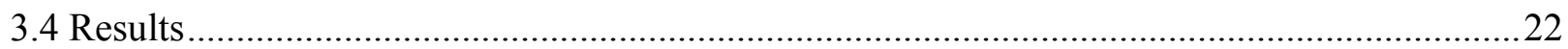

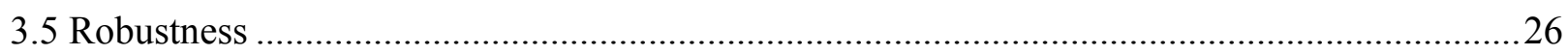

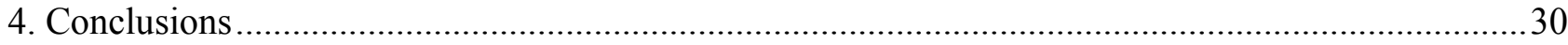

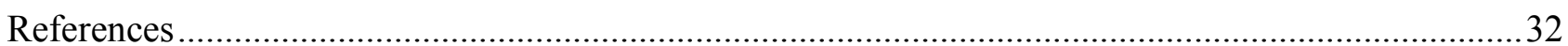

\footnotetext{
* All the authors are with the Bank of Italy. The opinions expressed are their own and do not necessarily reflect those of the Bank of Italy. Address correspondence to: pierluigi.bologna@bancaditalia.it.
} 



\section{Introduction ${ }^{1}$}

The economic and financial crisis that has overtaken Europe during the past four years has caused significant disruptions to the functioning of the banking system and the financial markets within the European Union and in particular within the Euro Area (EA). The process of financial integration and convergence towards a single financial market that had been under way for a number of years was abruptly halted by the crisis, triggering a reversal of the integration process, which was then reinforced by the re-emergence of country risks within the EA and by the related and perverse bank-sovereign feedback loop.

The increasing cross-border nature of banking during the pre-crisis period was not accompanied by an effective supervisory framework at the supranational level ${ }^{2}$ and therefore when the crisis hit the policy responses of national authorities were mostly uncoordinated. Thus, measures that were often rational from a purely domestic perspective had negative externalities and spill-over effects beyond domestic borders, affecting competition and creating arbitrage opportunities. At times these posed a threat to regional financial stability and reinforced mistrust in the financial markets. The bank domestic bias has certainly been exacerbated by the crisis, but it is also likely that the ring-fencing initiatives put in place within the EA have been partly responsible for the fragmentation of the regional banking system. ${ }^{3}$ To quote former Bank of England governor Mervyn King, the current crisis has shown clearly that "banks are global in life but national in death" ${ }^{4}$ despite the existence of a common global regulatory framework.

The result of this process has been a complex dynamic of fragmentation and re-nationalization of the Eurozone banking and financial system, with negative effects on its stability, the monetary policy transmission mechanism and the escalation of tensions on sovereign debt. ${ }^{5}$ To counter the situation described and in an attempt to restore normal conditions for monetary policy the European Central Bank (ECB) announced an escalation of accommodative and unconventional policy measures that have been playing a key role lately in reducing fragmentation and enhancing the conditions for financial stability. ${ }^{6}$

The aim of this paper is to move the analysis of the segmentation of the EA banking market one step forward from the present understanding of the phenomenon. We contribute to the literature by $i$ ) reviewing the evolution of cross-border banking in the EA from the pre-crisis period to the sovereign debt crisis period and ii) providing a prime assessment of the drivers of banks' pull-back within domestic borders during the crisis.

The paper is organized as follows. In Section 2 we present stylized facts of the segmentation of the EA banking system, both in terms of quantities and prices. In Section 3 we discuss the rationale for the empirical analysis, the data, the econometric methodology, the results and the robustness checks. In Section 4 we conclude.

\footnotetext{
${ }^{1}$ We thank Piergiorgio Alessandri, Paolo Angelini, Stijn Claessens, Fabio Panetta, an anonymous referee and participants at the IMF Workshop on Repairing the Euro Area Banking System: Developments and Policy Challenges, the FDIC $13^{\text {th }}$ Bank Research Conference, and the seminars at the Banca d'Italia and the Federal Reserve Board for useful comments and discussions during the various stages of the work. We are also grateful to Silvia Sgherri for providing us with the data on the first principal component of Euro Area sovereign spreads. The views expressed in this paper are those of the authors only and do not necessarily reflect those of the Banca d'Italia.

${ }^{2}$ Allen et al. (2011).

${ }^{3}$ Cerutti et al. (2010) and Morgan Stanley (2012).

${ }^{4}$ Turner (2009).

${ }^{5}$ International Monetary Fund (2012) and European Central Bank (2012a).

${ }^{6}$ Draghi and Constâncio (2013).
} 


\section{Fragmentation of the EA banking and financial system: stylized facts}

\subsection{Cross-border banking}

The dynamics of cross-border banking provide strong evidence of the EA banking system's segmentation. Banks headquartered in the Eurozone have reduced their cross-border exposures considerably since the onset of the global financial crisis, and especially from the summer of 2011, as shown by data on bank foreign claims published by the Bank for International Settlement (BIS) (2012). ${ }^{7}$

BIS data provide a clear and reliable picture of cross-border banking at aggregate level by country of residence, which allows us to identify a number of stylized features. Total gross consolidated foreign claims on an immediate risk basis of banks headquartered in EA countries decreased by 35 per cent from the peak in March 2008 (11,696 billion euros) to June 2012 (7,579 billion euros), returning to levels previously seen at the end of 2005. The decline was more pronounced for claims on EA countries (-40 per cent) than for those vis-à-vis non-EA countries (-32 per cent).

As shown in Figure 1, Eurozone banks have sharply reduced their activities abroad since the beginning of the crisis, ranging from a decrease of 8 per cent for Portuguese banks to 80 per cent for Belgian ones between March 2008 and June 2012. Notable exceptions are the Spanish banking system, which has seen its gross foreign claims grow by 29 per cent as a result of its exposures outside the EA (mainly in Latin America) and the Finnish and Greek banking systems, whose exposures are small, however. The retrenchment in cross-border banking by EA banks was not limited to the first period of the crisis (the global financial crisis) but continued to affect all countries' banking systems when the sovereign debt crisis directly hit the Eurozone. From June 2011 to June 2012, foreign exposures - especially towards member countries - declined from 3 per cent for the Spanish banks to 61 per cent for the Irish ones. The segmentation of the banking system is an EA phenomenon and does not involve, except marginally, the major banking systems outside the EA (namely in the UK, US and Japan), which continued to expand their international operations, although only in non-EA countries (an exception is the Swiss banking system, which reduced its foreign claims).

\footnotetext{
${ }^{7}$ In this work terms like “cross-border exposures”, “foreign assets”, etc. are used interchangeably for the term "foreign claims” adopted by the BIS.
} 
Figure 1. EA banks' gross foreign claims

on EA and non-EA countries (1)

(billions of euros)

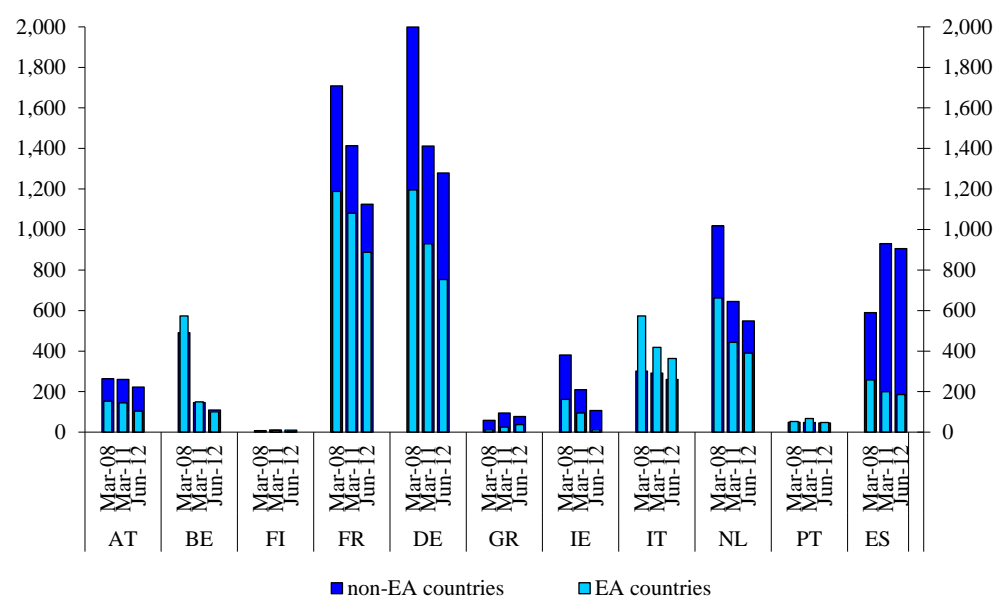

Source: Based on the consolidated exposures of national banking systems published by the BIS.

(1) Claims are measured on a consolidated basis and assigned to the country of residence of the parent company. Data are converted into euro at the end of period.

The re-nationalization of the EA banking system can also be observed through the reduction in the density of the network of cross-border exposures over time. Figure 2 provides a snapshot of bilateral cross-border exposures at the March 2008 peak of cross-border banking activity, towards the end of the global financial crisis in March 2011, and in June 2012.

\section{Figure 2. EA banks’ gross foreign claims (1)}

Peak of financial integration

(March 2008)

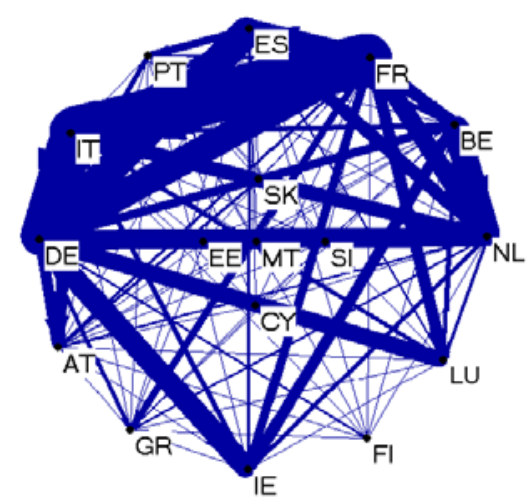

End of the global financial crisis

(March 2011)

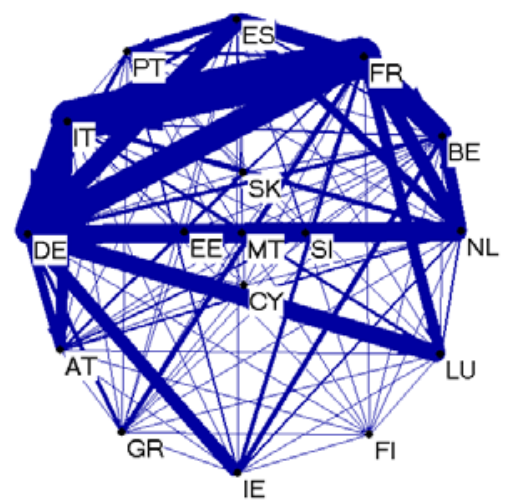

After the sovereign debt crisis (June 2012)

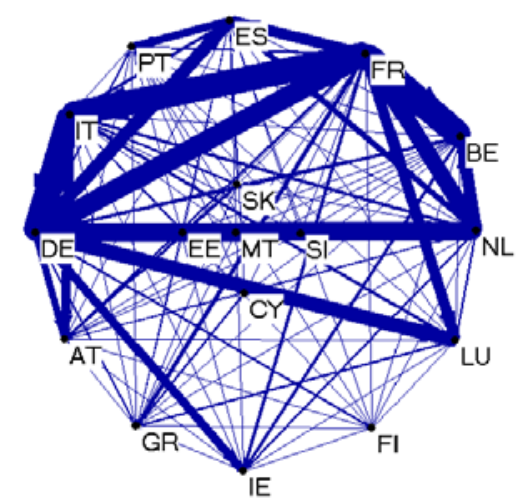

Source: Based on the consolidated exposures of national banking systems published by the BIS.

(1) Claims are measured on a consolidated basis and assigned to the country of residence of the parent company. Data are converted into euro at the end of period.

To complete the picture of the fragmentation of the EA banking system in Figure 3 we look at the breakdown of banks' foreign exposures by the sector of the counterparts. However, due to limitations in data availability, we need to restrict our focus to the period of the most acute sovereign debt 
tensions, from June 2011 to June 2012, and to a smaller sample of reporting countries (i.e. Germany, Italy, Spain and France). We nonetheless complement the picture by reporting the exposures, at aggregate level, for the main non-EA countries (i.e. US, UK, Switzerland and Japan). ${ }^{8}$ BIS data allows us to break down exposures by i) public, ii) banking, and iii) non-financial private sector. We use a heat map to show the changes (both in level and percentage) of foreign claims for each of three sectors above. Figure 3 confirms the broad picture that emerged from Figure 1 regarding the generality of the phenomenon in the EA, but a closer look shows that some notable differences exist across countries and sectors.

\section{i) Cross-border exposures towards foreign public sectors (Figure 3, panel A)}

Banks in all countries, albeit with some separate features, have substantially rebalanced their exposures in favour of the EA sovereigns with sounder public finances. This is a clear indication of the flight to quality that took place with the heightened redenomination risk affecting the Eurozone at least until the ECB's announcement of the OMT. ${ }^{9}$ German and French banks have moved in the same direction. They even curtailed exposures vis-à-vis their reciprocal public sectors, indicating that segmentation and retrenchment occurred also between these two countries. Italian banks, and to a lesser extent Spanish banks, have been increasing their exposures toward EA sovereigns with sounder public finances while reducing exposures towards non-EA public sectors.

In terms of borrowing countries, Italian and Spanish public sectors, unlike the other main EA countries, have seen large outflows by banks from all the countries considered in Figure 3. However, the public sectors of countries under aid programmes are experiencing by far the largest (although only in relative terms) outflows by foreign banks.

\section{ii) Cross-border interbank exposures (Figure 3, panel B)}

Despite the fairly clear indications stemming from data on exposures towards foreign public sectors, the reorientation of the banking systems within national borders is even more evident when we look at cross-border interbank exposures. These show the full structural change that has taken place in the EA banking system and the challenges that this implies for future banking in the Eurozone. It confirms the systemic relevance of the segmentation, which is affecting banks in both core and weaker countries, without much distinction. Between June 2011 and June 2012, all banking systems cut their cross-border interbank exposures vis-à-vis EA banks (and non-EA banks too). Over the period, exposures were reduced by between 6 percentage points for Spanish banks and 24 percentage points for French ones. In terms of counterpart banking systems, all suffered substantial outflows in aggregate, with very few bilateral exceptions.

The sector data on interbank foreign claims bear out the evidence that segmentation and renationalization are purely a Eurozone banking system issue, since business as usual took place for cross-border interbank claims outside the EA, as also found by Manna (2011) according to whom the home bias in interbank lending is much higher within the EA than outside it.

\footnotetext{
${ }^{8}$ Sectoral data are available on an ultimate risk basis only and as such, while broadly consistent, they are not fully comparable with the data used in the rest of the paper, which is on an immediate risk basis.

${ }^{9}$ European Central Bank (2012b).
} 


\section{Figure 3. Gross claims of the reporting countries' banks on foreign} counterparties by sector (1)

\section{(June 2011 - June 2012, billions of euros and percentage changes)}
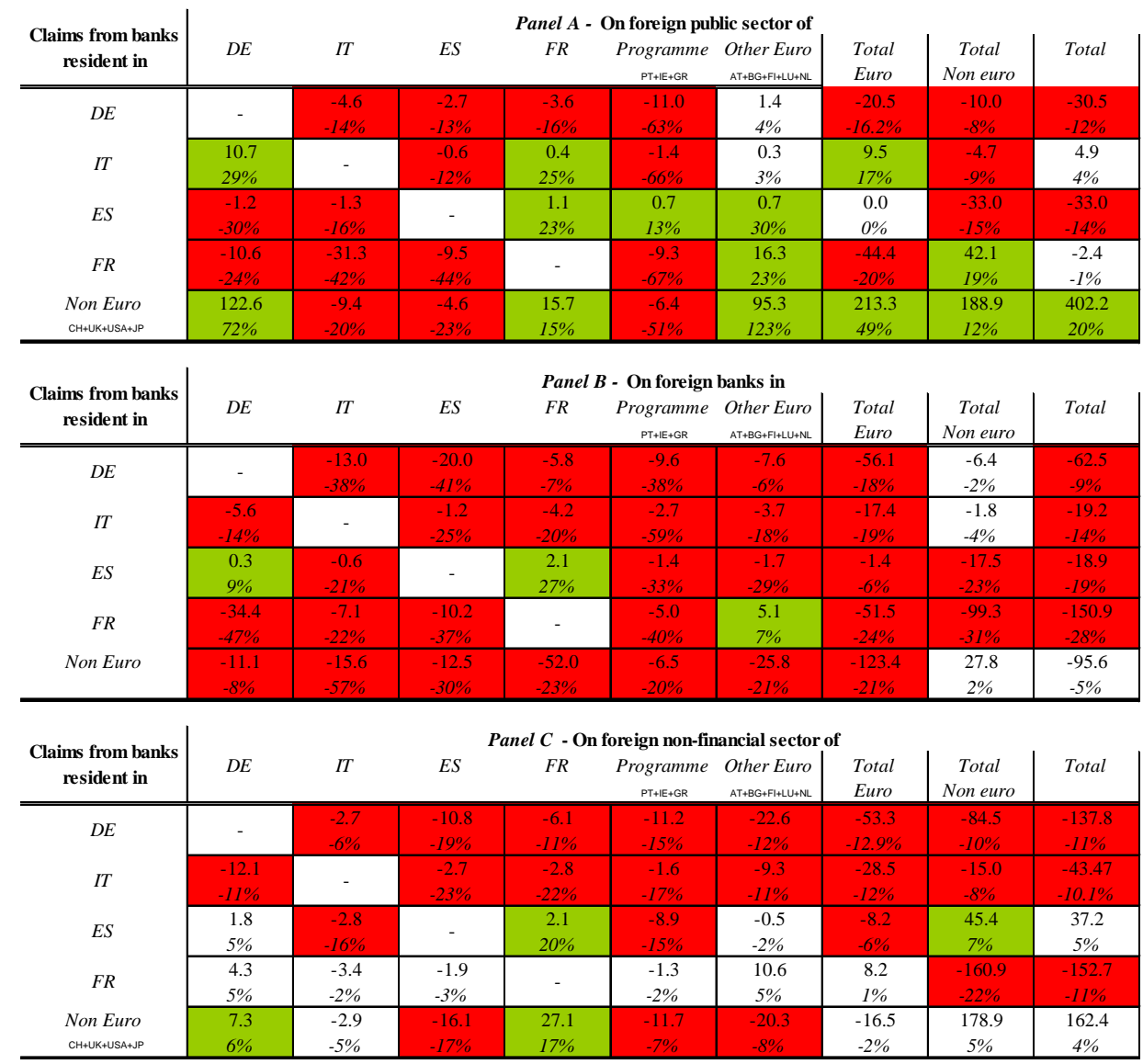

Source: Based on the consolidated exposures of national banking systems published by the BIS.

(1) Data do not include banks' claims on and liabilities to the Eurosystem. The data are converted into euros at the end of period.

\section{iii) Cross-border exposures towards the non-bank private sector (Figure 3, panel C)}

The integration of the EA banking system since the inception of the euro has been less strong for retail banking than for wholesale banking, with cross-border lending representing only a small share of total lending to non-banks before the crisis. ${ }^{10}$ Despite this evidence, however, re-nationalization is visible in the non-bank private sector as well. In the period June 2011-June 2012 most of the main EA banking systems reduced their EA exposures, with the sole exception of French banks, which recorded a marginal increase.

\subsection{Bank-sovereign link and a common EA factor}

The domestic retrenchment of EA banks since the beginning of the crisis can be assessed with respect to banks' exposures to domestic sovereigns. Figure 4 presents the times series of the foreign claims of

\footnotetext{
${ }^{10}$ According to ECB data, at the end of 2007 about 85 per cent of loans supplied by domestic credit institutions were to domestic residents, 12 per cent to residents of other EA countries and 3 per cent to residents of other EU countries. See Laeven and Tressel (2013) for more evidence on the degree of banking integration in the EA before the crisis, including in comparison with the US.
} 
EA banks, together with the quarterly growth rates of EA banks' exposures in their domestic sovereigns.

It can be seen that the quarterly growth of EA banks' domestic sovereign exposures was slightly negative before the crisis (with an average growth rate of -0.3 per cent from the first quarter of 2003 to the last quarter of 2007), when foreign claims were steadily growing, but then became largely positive during the crisis (averaging up to +2.4 per cent), when foreign claims started to decrease. The behaviour of the two aggregates over time suggests that the link between banks and domestic sovereigns became much closer during the crisis compared with the pre-crisis period.

The dynamics of EA banks' total foreign claims is also closely associated with the Eurostoxx 600 Banking Index, which can be seen as a proxy for common EA bank soundness and financial stability conditions. Figure 5 presents the two series for the period March 2003-June 2012: they show a surprisingly close co-movement for the entire period, suggesting that commonalities could also matter for banks' cross-border activity.

\section{Figure 4. EA banks' foreign claims and exposures towards domestic sovereigns}

(percentage changes and billions of euros)

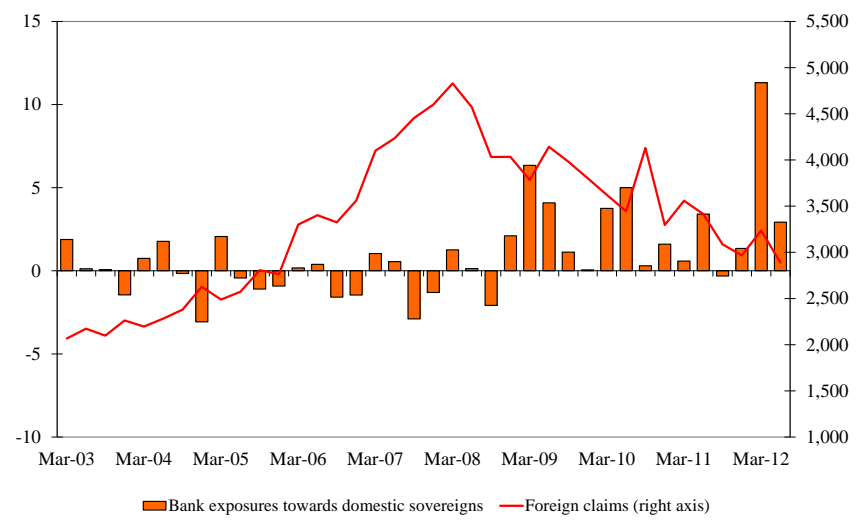

Source: Based on ECB and BIS data.

\section{Figure 5. EA banks' foreign claims and Eurostoxx 600 Banking Index}

(index points and billions of euros)

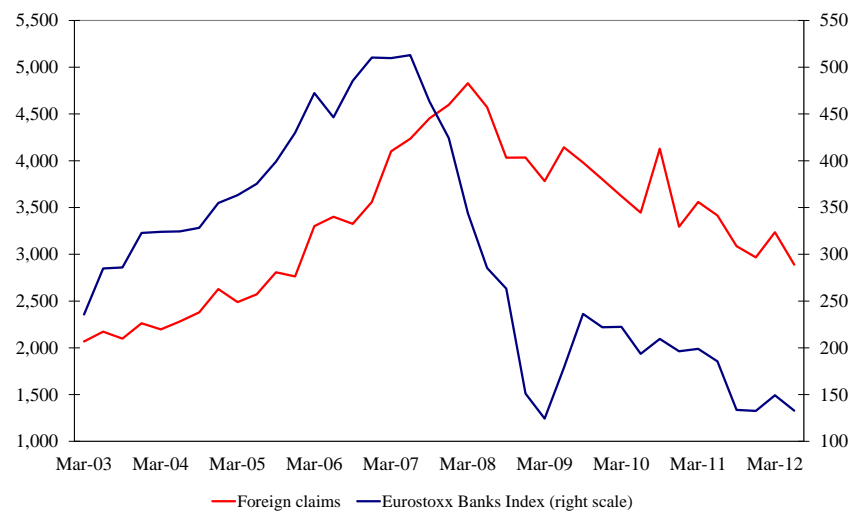

Source: Based on Datastream and BIS data.

\subsection{Interest rates on loans and deposits}

The increased cross-country heterogeneity of interest rates on the flow of new loans and deposits provides additional evidence of the segmentation of the Eurozone financial market and the reorientation of banking systems within domestic borders. The cross-country dispersion of loan and deposit interest rates, which had been low for several years after a long convergence process, widened considerably when the Lehman crisis struck in the autumn of 2008. The dispersion remained very high thereafter and increased further with the aggravation of tensions in the EA sovereign debt market in the summer of 2011, as shown in Figure 5. ${ }^{11}$

\footnotetext{
11 The increased heterogeneity of sovereign spreads across the EA affected the segmentation of the financial system even outside the banking system. Evidence of segmentation is also shown for the non-financial corporate bond market, where Pianeselli and Zaghini (2013) find that in the years 2010-2012 sovereign-specific factors weighted substantially more than they did in the pre-crisis years for corporate bond pricing.
} 
Interest rate dynamics between countries with better public finances (in the lower part of the light blue dotted area in both panels of Figure 6), countries with economic aid-programmes (in the top-part of the band, but not shown in Figure 6) and others (in the middle of the areas) are tripartite. The difference between the minimum and maximum interest rates on new loans and new deposits across EA countries increased from average values of 180 basis points (bp) and 60 bp respectively in the pre-crisis period (January 2003 - March 2008) to 383 bp and 314 bp in the following period (April 2008 - June 2012).

\section{Figure 6. Interest rates on loans and deposits in the EA countries (1)}

\section{Dispersion of EA loan rates}

(percentage points)

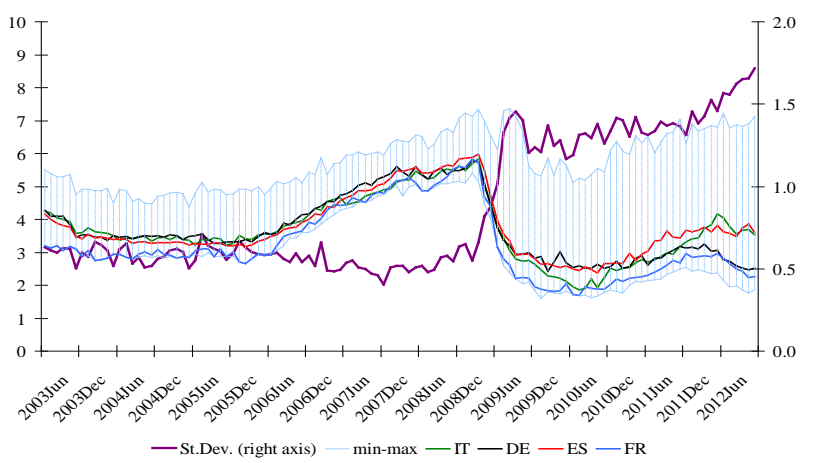

Source: Based on ECB data.

(1) Loans: rates on new loans to firms up to 1 million euros and with maturities up to 1 year. Deposits: rates on new deposits by firms and households with agreed maturities up to 1 year. Monthly data referring to transactions in euros, collected and compiled according to the Eurosystem's harmonized methodology.

Despite this evidence, looking only at loan rates we cannot rule out ex ante that the divergence of rates across countries could simply reflect the different credit risk faced by banks in different countries. Banking theory and practice in fact dictates that loan rates should reflect borrowers' riskiness, which could in turn depend on the economic cycle of the country in which borrowers operate. Hence, divergence of loan rates across countries per se might not be sufficient to indicate any systemic issue for the entire EA and/or group of countries. Under this assumption, however, with heterogeneity in borrowers and economic cycles across the EA being reflected on loan rates, customer deposit rates should be unrelated to loan rates owing to the explicit and implicit forms of guarantee they effectively enjoy. $^{12}$

A scatter plot of loan and deposit rates in EA countries before the crisis and during the crisis (Figure 7) shows that the above assumption holds true only before the crisis (December 2003 - March 2008) and then collapses during the first period of the crisis (April 2008 - March 2011) and during the sovereign debt crisis (April 2011 - June 2012).

\footnotetext{
${ }^{12}$ Monitoring by depositors (both non-financial corporates and households considered in this paper) tends to be relatively low as not all depositors are willing or skilled enough to exercise an adequate level of monitoring on banks' conditions, particularly in the presence of deposit insurance schemes, such as those existing in the EA (see Bologna (2013) for a review of the discussion on the role of depositors and their disciplinary effect on intermediaries).
} 


\section{Figure 7. Loan and deposit rates in the EA before and after the beginning of the crisis}

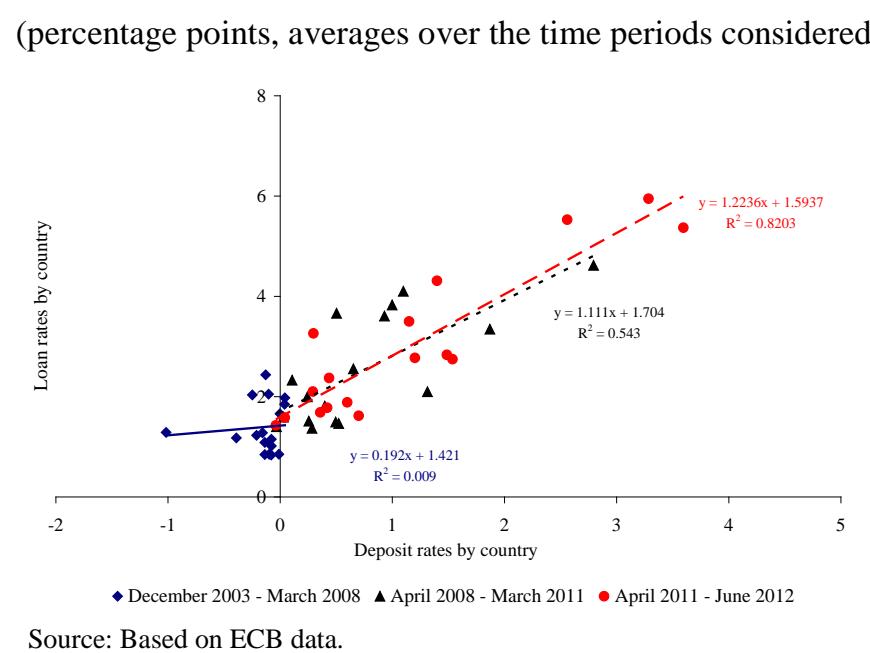

The emergence of a strong correlation in the second period confirms the anomaly of the situation, with retail funding costs reflecting heightened risks of a systemic nature - such as sovereign risk, contagion risk and redenomination risk. Financial instability and significant threats to the solidity of the institutional set-up are therefore likely to be at the root of the segmentation, affecting market conditions for government securities first, and then those for loans and deposits. ${ }^{13}$

\subsection{Crisis-driven policy measures}

Other features of the segmentation of the EA banking system are the uncoordinated policy and supervisory measures adopted by a number of authorities in Europe and in the EA. To give only a few examples, regulatory authorities in Croatia, Poland and Turkey issued recommendations to withhold profit distributions by subsidiaries of foreign banks despite strong fundamentals (Cerutti et al., 2010) and the Polish authorities introduced increases in risk weightings on mortgage loans in foreign currencies (Kruszka and Kowalczyk, 2011). Authorities in other countries (Germany, Austria, UK, etc.) issued measures such as limits on credit growth, unilateral increases in capital standards and limits on intra-group cross-border liquidity transfers (Morgan Stanley, 2012). While all these measures might be considered appropriate from a purely domestic perspective, if taken in an uncoordinated fashion they have a protectionist connotation which, from a single-market perspective, only worsens and deepens the balkanization of the EA banking system.

\footnotetext{
${ }^{13}$ On this issue evidence has also been provided by Angelini et al. (2013).
} 


\section{The dynamics of EA cross-border banking: an empirical assessment}

\subsection{Motivation}

We now move to investigate the dynamics of cross-border banking within the EA to assess the drivers of intra-area cross-border banking activity. In particular, we aim to address three main questions:

a) Is cross-border banking driven by home and host country conditions?

b) Does their international organizational structure matter for banks' retrenchment?

c) Did EA system-wide factors play a role during the crisis in driving banks' retrenchment?

With regard to home and host country conditions (sub $a$ ), at least four groups of factors can be expected to affect bank decisions about cross-border banking: i) home and host countries' macroeconomic and public finance situation; ii) banks’ portfolio choices; iii) host country external vulnerability; iv) additional country-specific factors relating to, among other things, the banking system structure, supervisory policies, but also differences in cultural, language and business practices.

i) Home and host countries' macroeconomic and public finance situation. We expect more favourable macroeconomic and public finance conditions in both home and host countries to give banks stronger incentives to develop their business both domestically and, relevant for our analysis, across borders or to retrench less during the crisis. The opposite would be true under less favourable conditions.

ii) Banks' portfolio choices. Factors affecting banks' portfolio choices would also involve foreign exposures and hence drive changes in cross-border activity

- The bank-sovereign link could be a first factor to help explain banks' home bias during the crisis: we expect banks more closely intertwined with their domestic sovereign to face greater difficulties in keeping or expanding their business abroad, especially when domestic sovereign conditions worsen.

- In the context of a broader risk-reduction strategy banks may also seek to reduce the concentration of their foreign claims portfolio: a higher concentration could therefore drive negative changes in banks' asset allocation beyond domestic borders.

- Host-country specific factors are also likely to play a role. One of the first of such factors is the financial attractiveness of the host country: banks would in fact have an incentive to increase their exposure towards countries with more profitable risk-adjusted investment conditions (i.e. with higher interest rates and sound public finances). At the same time, however, there could also be circumstances in which the soundness of the host country per se prevails and banks have an incentive to increase their foreign exposure even towards the less profitable host countries in order to find a safe harbour during the storm (i.e. flight to quality). The attractiveness of a host country could also be signalled ex-ante by its external vulnerability: hence banks would retrench more from the countries with a higher dependence on foreign banking. This expectation could be affected by cases in which political pressures help to deter foreign banks' retrenchment in order to avoid an excessive displacement for the entire economy because domestic banks are unable to substitute for the retrenched foreign lending.

iii) Additional country-specific factors. The country-specific factors and cross-country differences that could play a role in determining banks' cross-border activity are differences in 
supervisory policies - which during the crisis were sometimes shaped to ring-fence foreign assets structural differences in the banking systems, and also differences in culture, language and legal system, as shown by Buch (2003) and Buch et al. (2010).

As part of this narrative, we think that the form of banks' international organization could also play a role in banks' retrenchment during the crisis (question sub $b$ ), as it has been argued occurs for crossborder banking during normal times by Cerutti et al. (2007) and Dell'Ariccia and Marquez (2010), who investigate the organizational choice of banks for cross-border activity. There are likely to be differences in the banks' business focus when operations are carried out through foreign branches and/or subsidiaries as opposed to when they are carried out from the banks' home headquarters: banks with a physical presence in a foreign country are more likely to carry out traditional commercial banking (i.e. corporate and retail), while banks operating from their home country are likely to be more involved in wholesale operations, which are by nature more volatile than commercial banking. ${ }^{14}$ Banks operating in foreign countries through subsidiaries or branches can therefore be expected to be less prone to retrench, thanks to a deeper and more stable involvement in the fortunes of the host country than banks operating directly from their headquarters.

As for question sub c), concerning whether an EA system-wide factor plays a role in driving crossborder banking and banks' retrenchment in addition to country-specific factors, we rely on the empirical evidence on pricing provided by Sgherri and Zoli (2009), according to which EA sovereign risk premium differentials tend to co-move over time and are mainly driven by a common time-varying factor. ${ }^{15}$ In addition, Sgherri (2012) suggests that in the Eurozone sovereign debt crisis commonalities have played a greater role in pricing dynamics, ${ }^{16}$ reflecting the risk of a possible break-up of the single currency area. Hence, we argue that cross-border activity could also be driven by EA system-wide factors, which we expect to be potentially significant in normal conditions and even more so when the crisis erupts and EA sovereign tensions grow more acute. In other words, we expect that if there were a real threat of a possible EA break-up, an EA-wide factor would also be a significant driver of banking system segmentation in the EA.

\subsection{A conceptual framework for EA cross-border banking}

We assess the dynamics of cross-border banking in the EA accounting for both push and pull factors. ${ }^{17}$ The framework is inspired by the family of gravity models, typically applied to study bilateral trade, but substantially departs from it in a number of ways. The gravity framework, initially developed by Tinbergen (1962) to explain the bilateral trade volume with the distance between two countries and their GDPs, has since also been used in the literature on international finance to study cross-border financial flows as in Portes and Rey (2005), Lane and Milesi-Ferretti (2008) and Okawa and van Wincoop (2012). In our framework we consider some typical gravity model variables, such as the distance between countries, but we also introduce additional macroeconomic and financial sector

\footnotetext{
${ }^{14}$ Fiechter et al. (2011) depict the operational differences between foreign branches and subsidiaries. We extend their argument by including the cross-border operations carried out from the banks' headquarters, which are on the opposite side of the spectrum relative to foreign subsidiaries in terms of banks' local involvement in the foreign countries.

15 Bruno and Shin (2013) also find support for global factors driving capital flows in a panel of 46 countries - both advanced and emerging economies - with significant and open banking sectors.

${ }^{16}$ Sgherri (2012) points out that risk commonalities dominated market pricing dynamics in the EA during the crisis and country-specific risk factors were also important but their contribution was modest.

17 "Push and pull factors" is a term usually adopted when discussing human migration. In particular, following Lee (1966), push factors are unfavourable aspects of the area that one lives in and pull factors are elements that attract one to another area. In the context of this paper, push factors and pull factors can be referred respectively to home (lending) and host (borrowing) country conditions that push or pull banks to increase or reduce their cross-border activity.
} 
variables to assess the relevance of the lending (home) and borrowing (host) country conditions, and we account for the role of information frictions.

Our dependent variable $\Delta F C_{i, j, t}$, in line with Laeven and Tressel (2013), is defined as the growth in foreign claims from banks in country $i$ towards country $j$ in period $t$. We therefore use a delta stock to approximate the flows between each pair of countries as we are interested in modelling the bilateral changes in bank cross-border activity. ${ }^{18} \Delta F C_{i, j, t}$ is winsorized at 1 and 99 per cent to reduce the effect of any spurious outliers.

In particular, we estimate the following model:

$$
\Delta F C_{i, j, t}=\alpha_{0}+\beta_{1} \text { Macro }_{i, t-1}+\beta_{2} \text { Macro }_{j, t-1}+\beta_{3} \text { Distance }_{i, j, t}+\beta_{4} \text { PTF }_{i, j, t-1}+\beta_{5} \text { Ext_vul }_{i, j, t-1}+\beta_{6} \text { Common }_{E A, t-1}+\gamma_{c}+\varepsilon_{c, t}
$$

The independent variables include: macroeconomic variables for each home and host country, measures of distance between each pair of countries, variables depicting the portfolio choices of banks in country $i$ in terms of both prices and quantities, a measure of country $j$ 's vulnerability to capital outflows, a common EA factor, a variable capturing major cross-border M\&As, and country fixed effects.

We discuss here the rationale for the variables used and refer to Table 1 for a detailed description of how each variable has been computed and the data sources used.

Macro $_{i, t-1}$ and Macro $_{j, t-1}$, standard elements of a gravity model, aim to capture the relevance of each country's economy. However, unlike a gravity model, we look at the change in macroeconomic conditions rather than at the size of the economy, as this is more appropriate to model our dependent variable, which is in dynamic terms. We use the changes in industrial production $\left(\Delta I P_{i, t-1}\right.$ and $\left.\Delta I P_{j, t-1}\right)$ to control for growth conditions and the changes in the debt-to-GDP ratio ( $\Delta D e b t_{i, t-1}$ and $\left.\Delta D e b t_{j, t-1}\right)$ to control for the dynamics of the countries' fiscal positions.

Distance $_{i, j, t}$, which we measure as the distance between the capital cities of country $i$ and country $j$ (Distance_k $m_{i, j}$ ), is a standard gravity model control. While in principle the existence of a border between the lender and the borrower should not play any particular role for financial flows - unlike what can be expected for trade - the empirical literature suggests that the physical distance does indeed matter (Buch, 2003). We argue that the physical distance can be interpreted as a proxy for information frictions due to differences in institutional systems, market practices and cultures.

We also think, however, that an additional measure of distance, which goes beyond the concept of physical distance between countries, could also reflect information frictions and drive banks' foreign claims: this the distance between countries in terms of financial conditions. Distance_rates ${ }_{i, j, t-1}$ is therefore measured as $\left|r_{d, j, t-1}-r_{d, i, t-1}\right|$, which is the absolute value of the difference between the retail deposit rates in country $j$ and $i$ and therefore the distance of funding conditions between banks in country $i$ and those in country $j$. For this variable to adequately isolate the negative effect of the

\footnotetext{
${ }^{18}$ We are aware that using changes in stock variables to proxy flows is not necessarily an optimum solution, particularly considering the volatility observed in market prices for some asset classes during the crisis. This, however, is the only possible solution with the data available.
} 
absolute distance between EA countries' financial conditions on banks' foreign claims we also need to control separately for those cases in which the sign of the above difference in absolute terms could also matter for banks. We do so with price variables included in the group of banks' portfolio allocation controls, $P T F_{i, j, t-1}$.

The portfolio allocation variables $P T F_{i, j, t-1}$ include both pricing and quantity variables. The price variables, included in the model in line with Stock and Yogo (2005), ${ }^{19}$ aim to control for the price incentives for banks in country $i$ to increase their exposure in country $j$. These incentives are proxied by the difference in the prevailing interest rates between country $j$ and country $i$ and the fiscal conditions of country $j$.

We consider two cases: one in which the deposit rate in the borrowing country $j$ is higher than the one in the lending country $i$ and the other when the relationship is the opposite. If $r_{d, j, t-1}>r_{d, i, t-1}$ banks in country $i$ may have an incentive to increase their exposure towards the more profitable country $j$ when the risks in country $j$ are low enough. ${ }^{20}$ We could therefore expect this positive difference in rates to be significant in driving an increase in foreign claims from banks in country $i$ to country $j$, provided that the risk profile of country $j$, as proxied by its fiscal conditions, is sound enough. Hence, as a pricing variable to measure bank incentives to increase foreign lending to country $j$ we use Investment $t_{i, j, t-1}$, which is equal to the interaction of the difference in interest rates between country $j$ and country $i$ with country $j$ debt-to-GDP ratio if the difference in interest rates is positive, and to zero otherwise. ${ }^{21}$

There could be also a situation in which banks in country $i$ have an incentive to increase their exposure towards country $j$ even if rates in country $j$ are lower than in country $i$, i.e. $r_{d, j, t-1}<r_{d, i, t-1}$. This is likely to happen in a crisis environment as a flight-to-quality type of behaviour, which would take place when fiscal conditions in country $j$, and hence the country risk profile, were substantially more favourable than those in country $i$. Under these circumstances banks in country $i$ could be willing to give up a potential profit in exchange for a safe-haven type of investment. To capture this we use the price variable $F T Q_{i, j, t-1}$ equal to the interaction of the difference in interest rates between country $j$ and country $i$ with country $j$ debt-to-GDP ratio if the difference in interest rates is negative and to zero otherwise. $^{22}$

The choice of the retail deposit rates rather than the loan rates to build the interest rate variables Investment $_{i, j, t-1}$ and $F T Q_{i, j, t-1}$ is driven by the idea that deposit rates can be expected to be nearly riskfree rates (thanks to deposit insurance and implicit guarantees) and hence, within a single currency area, very close to each other. Any divergence could therefore represent either a temporary true

\footnotetext{
${ }^{19}$ Stock and Yogo (2005) propose a procedure to test for weak instruments. The procedure is a two-stage estimate where in the first stage the variables of interest are regressed on the instruments to check whether the instruments are valid (Stock and Yogo provide critical values for the F-test). Then in the second stage a full information maximum likelihood is used including the instruments in the regression. Our price variables may be interpreted as instruments and our choice to estimate them together with the other variables in the model is in line with the second stage proposed by Stock and Yogo (2005).

${ }^{20}$ Or equally, banks in country $j$ would have an incentive to increase their funding at the cheaper conditions prevailing in country $i$.

${ }^{21}$ More precisely, for measurement purposes, we use the inverse of the debt-to-GDP ratio as we want an increase in the variable to indicate an improvement in the country's fiscal position, and thus for the variable to move in the same direction as the interest rate differential.

${ }^{22}$ As with the previous interacted variable, here we again use the inverse of the debt-to-GDP ratio as we want an increase in the variable to indicate an improvement in the country's fiscal position, and thus for the variable to move in the same direction as the interest rate differential. Moreover, in this case the difference in interest rates between country $j$ and country $i$ is expressed in absolute value.
} 
investment opportunity or a possible market dysfunction. Differences in loan rates could instead simply reflect different levels of borrowers' credit risk across countries and hence would be inappropriate to capture the phenomena we are interested in. ${ }^{23}$

The next portfolio allocation variables are quantity based. As the first quantity based variable for portfolio allocation we use $\triangle B E T S_{i, t-1}$ which measures the change in the bank-sovereign link for the lending country $i{ }^{24}$ This is given by the quarterly change in country $i$ banks' exposures towards their domestic sovereign. We expect that the tightening of the bank-sovereign link during the crisis may have contributed to the fragmentation of the EA banking system.

The last quantity based portfolio variable is a measure of foreign claims concentration by country $i$ : $\frac{F C_{i j, t-1}}{F C_{i, t-1}}$ is the share of foreign claims from banks in country $i$ to country $j$ on country $i$ total banking system foreign claims.

As for the external vulnerability Ext_vul ${ }_{i, j, t-1}$ we define two variables for the borrowing country $j$ 's dependence on foreign banks and therefore for its vulnerability to capital outflows. In particular, following Laeven and Tressel (2013) we use $\frac{F C_{j, t-1}}{\text { Asset }_{j, t-1}}$ to measure the overall dependence of country $j$ on external liabilities to banks and $\frac{F C_{i j, t-1}}{\text { Asset }_{j, t-1}}$ to measure the dependence of country $j$ on external liabilities to banks in a given country $i$. These two variables allow us to test whether a higher dependence of country $j$ on external liabilities tout court or on external liabilities to a single country $i$ matter for country $i$ banks' decision to invest in $j$, as found by García Herrero and Martìnez Perìa (2007).

Starting from the specification of the single-country dependence variable $\frac{F C_{i j, t-1}}{\text { Asset }_{j, t-1}}$ we then introduce a differentiation concerning how banks in country $i$ carry out their cross-border operations in a given country $j$. The differentiation is among the cross-border operations carried out through foreign branches, foreign subsidiaries or directly from the country where banks are headquartered (i.e. under "freedom to provide services"). To this end we define three variables Branches $i j$, Subsidiaries ${ }_{i j}$, and $H Q_{i j}$ as the interactions of dummies taking the value 1 if banks in country $i$ have branches (at least one branch but no subsidiaries), subsidiaries, or neither of the two in each country $j$, with the single-country dependent variable $\frac{F C_{i j, t-1}}{\text { Asset }_{j, t-1}}$.

The last set of variables in our model is Common $_{E A, t-1}$ to control for the role of common factors, in addition to the country-specific factors, in the segmentation of the EA banking market during the crisis. ${ }^{25}$ We start by including $\Delta$ Equity $_{E A, t-1}$ as the returns of the Stoxx Europe 600 Banking Index: this variable can be expected to proxy common conditions across the EA banking sector, which were

\footnotetext{
${ }^{23}$ We test the robustness of this argument later in the paper by estimating a model with loan rates.

${ }^{24}$ For this variable the same note of caution previously mentioned for the dependent variable concerning the use of changes in stocks to proxy flows is necessary.

${ }^{25}$ As also found by Hermann and Mihaljek (2013) analysing cross-border bank flows to emerging markets during the 20072008 crisis.
} 
particularly significant during the crisis. We also expect redenomination risk to be a possible common driver of home bias during the period of sovereign tensions and this might be better captured by more targeted variables. We therefore use two additional variables to test for redenomination risk: $i$ ) $\Delta$ Spread $_{E A, t-1}$ are the changes in the commonality of EA sovereign spreads as measured by the first principal component of sovereign spreads (Sgherri, 2012); ii) Google GA,t-1 $_{1}$ is an index based on the search frequency of keywords relating to the break-up of the EA in the Google search engine.

The model includes home and host country dummies $\gamma_{c}$ to control for any additional country-level effect that is not captured by the other variables used, namely country-specific supervisory policies and practices as well as banking system structures.

Finally, to isolate the possible jumps in banking flows due to international banks' mergers and acquisitions and to banks' split-ups, as happened for Fortis in 2008 and Dexia in 2011 in response to their crisis, we include a dummy variable $M \& A$ that is equal to 1 for the extreme values of our dependent variable $\Delta F C_{i, j, t} \cdot{ }^{26}$

To address possible endogeneity concerns for contemporaneous observations all time-dependent explanatory variables enter the model with a lag. This is normally equal to one quarter as we use quarterly observations. However, lagging by one quarter the high frequency market variables, such as equity index returns and interest rates included in the model, would capture information on average three months older than the observed dependent variable in each quarter. Given the volatility of financial markets this lag is therefore too long and would very probably deprive the variable of its explanatory information content. Hence lagging the market variables by one quarter would entail a severe trade-off between a substantial loss of information content and the benefit of addressing the possible endogeneity. To deal with this trade-off we therefore lag the market variables by less than one quarter (see Table 1). With this choice we still address possible endogeneity concerns by preserving a clear cut-off between the time of observation of the dependent variable and that of the explanatory variables while also trying to use as much of the relevant information as possible.

We expect the importance of the explanatory variables described above to change over time in the light of the structural changes that have overtaken EA banks' business strategies from the pre-crisis period to the crisis, partially driven by exogenous regulatory constraints. To account for such inter-temporal discontinuity we estimate the model over three different sub-periods, which we believe reflect three different business environments for EA banks. These phases are defined as follows: i) Pre-crisis: financial integration (2003Q1-2008Q1); ii) Global financial crisis: segmentation begins (2008Q22011Q1); and iii) Sovereign debt crisis: segmentation worsens (2011Q1-2012Q2).

\footnotetext{
${ }^{26} M \& A$ is equal to 1 for values falling below 0.01 per cent and above 99.9 per cent of the whole distribution (across all countries and in all quarters) of the dependent variable. While the results are overall robust to less stringent thresholds, those chosen actually capture all the more relevant international bank reorganizations that occurred before and during the crisis. Moreover, as previously mentioned, to reduce the effect of any spurious outliers the dependent variable is winsorized at 1 and 99 per cent.
} 


\section{Table 1. List of key variables}

\begin{tabular}{|c|c|c|c|}
\hline Category & Mnemonic & Data source & Description \\
\hline $\begin{array}{l}\text { Dependent } \\
\text { variable }\end{array}$ & $\Delta \mathrm{FC}_{\mathrm{ij}, \mathrm{t}}$ & BIS and ECB & $\begin{array}{l}\text { Cross-border lending: quarterly growth of foreign claims from banks in country i to country } \mathrm{j} \text { in } \\
\text { period t, measured by the ratio between the change in total gross foreign claims from country i to } \\
\text { country j between quarter t- } 1 \text { and quarter } \mathrm{t} \text {, and total banking system assets of country i at time t- } \\
\text { 1. Foreign claims are the consolidated foreign claims of national banking systems on an immediate } \\
\text { risk basis (Bank for International Settlements, 2012). BIS data, reported in USD, have been } \\
\text { converted into euros at the end-of-period exchange rate for all EA countries. }\end{array}$ \\
\hline \multirow{2}{*}{ Macro } & $\Delta \mathrm{IP}_{\mathrm{i}, \mathrm{t}-1}$ and $\Delta \mathrm{IP} \mathrm{P}_{\mathrm{j}, \mathrm{t}-1}$ & Eurostat & $\begin{array}{l}\text { Quarterly growth of the monthly Industrial Production Index for each country i and j. Data is } \\
\text { working day and seasonally adjusted. The variables enter the equations lagged by one quarter } \\
\text { relative to the dependent variable. }\end{array}$ \\
\hline & $\Delta$ Debt $_{\mathrm{i}, \mathrm{t}-1}$ and $\Delta$ Debt $_{\mathrm{j}, \mathrm{t}-1}$ & Eurostat & $\begin{array}{l}\text { Quarterly growth of the general government consolidated gross debt as a percentage of GDP for } \\
\text { each country } \mathrm{i} \text { and } \mathrm{j} \text {. The variables enter the equation lagged by one quarter relative to the } \\
\text { dependent variable. }\end{array}$ \\
\hline \multirow[b]{2}{*}{ Distance } & Distance_Km $\mathrm{K}_{\mathrm{i}, \mathrm{j}}$ & HorologeParlante & Natural logarithm of the distance between the capital of country i and country j, in kilometres. \\
\hline & Distance_rates $_{\mathrm{i}, \mathrm{j}}$ & ECB & $\begin{array}{l}\text { Difference in absolute value between the retail deposit rates of country j and country i. Deposit } \\
\text { rates refer to the new deposits in euros with agreed maturity up to } 1 \text { year of non-financial } \\
\text { corporations and households. The difference is calculated using the monthly data for the last } \\
\text { month of the quarter preceding the quarter of observation of the dependent variable. }\end{array}$ \\
\hline \multirow{4}{*}{$\begin{array}{l}\text { Portfolio } \\
\text { allocation }\end{array}$} & Investment $_{\mathrm{i}, \mathrm{j}, \mathrm{t}-1}$ & ECB & $\begin{array}{l}\text { Opportunity for banks in country } \mathrm{i} \text { to invest in country } \mathrm{j} \text { when rates in country } \mathrm{j} \text { are higher than in } \\
\text { country } \mathrm{i} \text { and country } \mathrm{j} \text { is fiscally sound (low debt-to-GDP ratio). The variable is equal to the } \\
\text { interaction between the Distance_deposit_rates and the inverse of the debt-to-GDP ratio of } \\
\text { country } \mathrm{j} \text { if the deposit rate in country } \mathrm{j} \text { is higher than the deposit rate in country } \mathrm{i} \text {, and zero } \\
\text { otherwise.The variable is calculated using the monthly data for deposit rates in the last month of } \\
\text { the quarter preceding the quarter of observation of the dependent variable. }\end{array}$ \\
\hline & $\mathrm{FTQ}_{\mathrm{i}, \mathrm{j}, \mathrm{t}-1}$ & ECB & $\begin{array}{l}\text { Flight-to-quality from banks in country i towards country } j \text { when rates in country j are lower than } \\
\text { in country } i \text { and country } j \text { is fiscally sound (low debt-to-GDP ratio). The variable is equal to the } \\
\text { interaction of the Distance_deposit_rates and the inverse of the debt-to-GDP ratio of country } j \\
\text { when the deposit rate in country } j \text { is lower than the deposit rate in country } i \text {, and zero otherwise. } \\
\text { The variable is calculated using the monthly data for deposit rates in the last month of the quarter } \\
\text { preceding the quarter of observation of the dependent variable. }\end{array}$ \\
\hline & $\Delta$ BETS $_{\mathrm{i}, \mathrm{t}-1}$ & ECB & $\begin{array}{l}\text { Quarterly growth of country i banks' exposure towards their domestic sovereign. The growth is } \\
\text { calculated as the ratio between the flow of the exposure towards the domestic sovereign in } \\
\text { quarter } t \text { and the stock of the exposure in quarter t-1. The variable enters the equation lagged by } \\
\text { one quarter relative to the dependent variable. }\end{array}$ \\
\hline & $\mathrm{FC}_{\mathrm{ij}, \mathrm{t}-1} / \mathrm{FC}_{\mathrm{i}, \mathrm{t}-1}$ & BIS and ECB & $\begin{array}{l}\text { Ratio of the outstanding gross foreign claims from banks in country } \mathrm{i} \text { to country } \mathrm{j} \text { as a share of the } \\
\text { total gross foreign claims by the banks in country i. The variable enters the equation lagged by } \\
\text { one quarter relative to the dependent variable. }\end{array}$ \\
\hline \multirow{2}{*}{$\begin{array}{c}\text { External } \\
\text { vulnerability }\end{array}$} & $\mathrm{FC}_{\mathrm{j}, \mathrm{t}-1} / \mathrm{ASSET}_{\mathrm{j}, \mathrm{t}-1}$ & BIS and ECB & $\begin{array}{l}\text { Ratio of the outstanding gross foreign claims received by country } \mathrm{j} \text { as a share of the total banking } \\
\text { system assets of country } \mathrm{j} \text {. The variable enters the equation lagged by one quarter relative to the } \\
\text { dependent variable. }\end{array}$ \\
\hline & $\mathrm{FC}_{\mathrm{ij}, \mathrm{t}-1} / \mathrm{ASSET}_{\mathrm{j}, \mathrm{t}-1}$ & BIS and ECB & $\begin{array}{l}\text { Ratio of the outstanding gross foreign claims from banks in country } \mathrm{i} \text { to country } \mathrm{j} \text { as a share of the } \\
\text { total banking system assets of country } \mathrm{j} \text {. The variable enters the equation lagged by one quarter } \\
\text { relative to the dependent variable. }\end{array}$ \\
\hline \multirow{3}{*}{ Common } & $\Delta$ Equity $_{\text {EA,t-1 }}$ & Datastream & $\begin{array}{l}\text { Monthly change in the Stoxx Europe } 600 \text { Banks Index in the last month of the quarter preceding } \\
\text { the quarter of observation of the dependent variable. }\end{array}$ \\
\hline & $\Delta$ Spread $_{\mathrm{EA}, \mathrm{t}-1}$ & Sgherri (2012) & $\begin{array}{l}\text { Monthly change in the first principal component of sovereign spreads in EA measured as in } \\
\text { Sgherri (2012) in the last month of the quarter preceding the quarter of observation of the } \\
\text { dependent variable. }\end{array}$ \\
\hline & Google $_{\mathrm{EA}, \mathrm{t}-1}$ & Bank of Italy & $\begin{array}{l}\text { Indicator of the search frequency of keywords relating to the break-up of the EA ("end of euro", } \\
\text { "end of the euro", "euro break-up", "euro break up", "euro breakup" and "euro exit") as inserted } \\
\text { in Google's search engine (Banca d'Italia, 2012). Monthly average of weekly data computed in } \\
\text { the last month of the quarter preceding the quarter of observation of the dependent variable. }\end{array}$ \\
\hline
\end{tabular}




\subsection{Data and summary statistics}

To build the variables needed for the analysis we use five main data sources as shown in Table 1: Bank for International Settlements (BIS) for bank foreign claims, DataStream for the banking sector stock market index returns, European Central Bank for banking data, Eurostat for macroeconomic data, and SNL Financial for banks international organization information. In particular, the dependent variable $\Delta F C_{i, j, t}$ is based on BIS data on consolidated foreign claims by EA country $i$ 's banking system, where $i$ corresponds to the following 11 (out of 17) EA countries reporting to the BIS: Austria, Belgium, Germany, Spain, Finland, France, Greece, Ireland, Italy, the Netherlands and Portugal. The data provides a break-down in terms of the $j$ countries towards which the foreign claims are directed, where $j$ is equal to all 17 EA countries, which are the same as the reporting countries plus Cyprus, Estonia, Luxemburg, Malta, Slovenia and Slovakia.

For the purpose of the analysis we use the consolidated foreign claims of national banking systems on an immediate risk basis (Bank for International Settlements, 2012). We prefer them to both the locational statistics and the consolidated data on an ultimate risk basis. With respect to the locational statistics, the consolidated foreign claims capture the claims of banking groups headquartered in the BIS reporting countries on a consolidated basis, i.e. including claims of their own foreign affiliates but net of all intragroup cross-border positions between related offices. ${ }^{27}$ With respect to the data on an ultimate risk basis, in which the claims are allocated to the country where the final risk lies, for those on an immediate risk basis the claims are allocated to the country of residence of the immediate counterparty, and hence they better reflect bank choices regarding cross-border banking. ${ }^{28}$ BIS data, reported in USD, are converted into euros at the end-of-period exchange rate for all EA countries.

Our sample involves quarterly observations from 2003Q1 to 2012Q2. Table 2 presents the summary statistics for our key variables and in each of the three sub-periods considered.

Table 3 reports the pairwise correlations for the same variables. Table 3 shows low but significant negative correlations between foreign claims and the dynamics of the countries' fiscal positions, as well as the physical and financial distances between countries. Foreign claims are also positively correlated with European banking equity index returns. These are, however, simple correlation coefficients and may depend on the influence of third variables.

\footnotetext{
${ }^{27}$ Locational data, compiled using principles that are consistent with the balance of payments, capture outstanding claims and liabilities of banking offices located in the BIS reporting countries, including cross-border positions between related offices belonging to the same group. See http://www.bis.org/statistics/about banking_stats.htm for more information about BIS international banking statistics.

${ }^{28}$ Our analysis is robust, however, to the use of foreign claims on an ultimate risk basis.
} 
Table 2. Summary statistics of the key variables

\begin{tabular}{|c|c|c|c|c|}
\hline & & $\begin{array}{c}\text { Pre-crisis: } \\
\text { financial integration } \\
\text { 2003Q1-2008Q1 } \\
\text { (i) }\end{array}$ & $\begin{array}{l}\text { Global financial crisis: } \\
\text { segmentation begins } \\
\text { 2008Q2-2011Q1 } \\
\text { (ii) }\end{array}$ & \begin{tabular}{|c} 
Sovereign debt crisis: \\
segmentation worsens \\
2011Q2-2012Q2 \\
(iii)
\end{tabular} \\
\hline Dependent variable & $\Delta \mathrm{FC}_{\mathrm{ij}, \mathrm{t}}$ & $0.042 \%$ & $-0.018 \%$ & $-0.031 \%$ \\
\hline Macro & $\begin{array}{l}\Delta \mathrm{IP}_{\mathrm{i}, \mathrm{t}-1} \\
\Delta \mathrm{IP}_{\mathrm{j}, \mathrm{t}-1} \\
\Delta \mathrm{Debt}_{\mathrm{i}, \mathrm{t}-1} \\
\Delta \mathrm{Debt}_{\mathrm{j}, \mathrm{t}-1}\end{array}$ & $\begin{array}{l}0.54 \% \\
0.68 \% \\
-0.13 \% \\
-0.41 \% \\
\end{array}$ & $\begin{array}{c}-0.88 \% \\
-0.85 \% \\
3.03 \% \\
3.87 \% \\
\end{array}$ & $\begin{array}{c}-0.49 \% \\
-0.42 \% \\
1.30 \% \\
1.59 \% \\
\end{array}$ \\
\hline Distance & $\begin{array}{l}\text { Distance_Km } \mathrm{i}_{\mathrm{i}, \mathrm{j}}(\text { in ln) } \\
\text { Distance_rates }_{\mathrm{i}, \mathrm{j}}\end{array}$ & $\begin{array}{c}7.07 \\
16 \mathrm{bp} \\
\end{array}$ & $\begin{array}{r}7.12 \\
68 \mathrm{bp} \\
\end{array}$ & $\begin{array}{c}7.13 \\
119 \text { bp } \\
\end{array}$ \\
\hline Portfolio allocation & $\begin{array}{l}\text { Investment }_{\mathrm{i}, \mathrm{j}, \mathrm{t}-1} \\
\text { FTQ }_{\mathrm{i}, \mathrm{j}, \mathrm{t}-1} \\
\Delta \text { BETS }_{\mathrm{i}, \mathrm{t}-1} \\
\text { FC }_{\mathrm{ij}, \mathrm{t}-1} / \mathrm{FC}_{\mathrm{i}, \mathrm{t}-1} \\
\end{array}$ & $\begin{array}{c}0.002 \\
0.003 \\
-0.21 \% \\
3.3 \% \\
\end{array}$ & $\begin{array}{c}0.007 \\
0.010 \\
3.77 \% \\
2.7 \% \\
\end{array}$ & $\begin{array}{c}0.007 \\
0.017 \\
3.30 \% \\
2.7 \% \\
\end{array}$ \\
\hline $\begin{array}{l}\text { Extemal } \\
\text { vulnerability }\end{array}$ & $\begin{array}{l}\mathrm{FC}_{\mathrm{j}, \mathrm{t}-1} / \mathrm{ASSET}_{\mathrm{j}, \mathrm{t}-1} \\
\mathrm{FC}_{\mathrm{ij}, \mathrm{t}-1} / \mathrm{ASSET}_{\mathrm{j}, \mathrm{t}-1}\end{array}$ & $\begin{array}{c}18.8 \% \\
2.2 \% \\
\end{array}$ & $\begin{array}{c}21.2 \% \\
2.4 \% \\
\end{array}$ & $\begin{array}{c}19.6 \% \\
2.2 \% \\
\end{array}$ \\
\hline Common & \begin{tabular}{|l|}
$\Delta$ Equity $_{\mathrm{EA}, \mathrm{t}-1}$ \\
Observations (Quarterly)
\end{tabular} & $\begin{array}{l}3.15 \% \\
2027\end{array}$ & $\begin{array}{l}1.42 \% \\
1660\end{array}$ & $\begin{array}{c}-4.38 \% \\
759\end{array}$ \\
\hline
\end{tabular}

Summary statistics refer to BIS reporting countries:

AT - BE - DE - ES - FI - FR - GR - IE - IT - NL - PT

Countries towards which foreign claims are directed:

AT - BE - DE - ES - FI - FR - GR - IE - IT - NL - PT and CY - EE - LU - MT - SI - SK

Table 3. Pairwise correlation matrix of the key variables

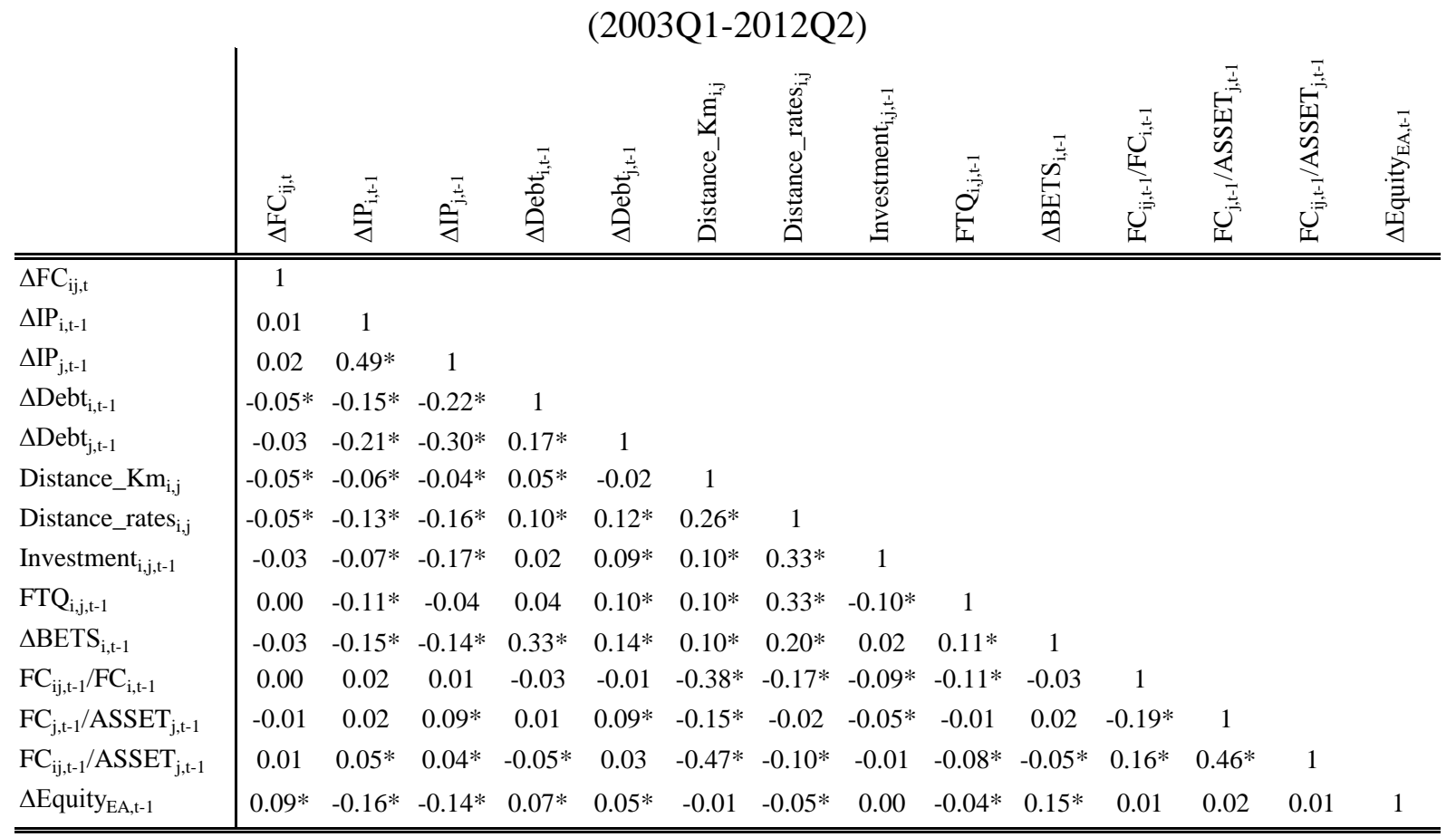

* Significant at $1 \%$. 


\subsection{Results}

Table 4 reports the results for the determinants of the changes in bilateral cross-border banking between each EA country taking into account both push and pull factors in the three periods under investigation. $^{29}$

\section{- Pre-crisis: financial integration (column i)}

In the tranquil period of financial integration the only significant factors that seem to drive foreign claims in the EA are the physical distance between capital cities Distance_km and the financial distance between countries Distance_deposit_rates ${ }_{i, j, t-1}$, so that growth in foreign banking is negatively related to both the distance variables. This finding is in line with the classical gravity framework. However, while the relevance of the physical distance in the case of bilateral trade is due to the existence of shipping costs, its interpretation is less obvious for cross-border banking. Our interpretation is that, during an ongoing financial integration process, the proximity of countries' cultural, sociological and institutional characteristics - proxied by the physical and financial distances - can be at the root of broader cross-border relationships between countries and hence also of banks' cross-border activity. ${ }^{30}$ At the same time, the negative sign observed for the financial distance also suggests that banks' crossborder operations increase with narrower cross-country interest rate differentials, consistently with what happened during the period of financial integration, with growing cross-border activity among banks and converging interest rates within the EA.

In principle, during this period one would have expected the growth in industrial production to be at work as well, although this is not the case. At the same time the non-significance of public finance, external vulnerabilities, portfolio allocation and the common banking variables is consistent with a generalized growth of foreign claims, under favourable macroeconomic conditions, low and converging interest rates and sovereign spreads, and stable banking systems, partly due to a probable misperception and mispricing of bank, macroeconomic and, more importantly, sovereign risks. ${ }^{31}$ Cross-country heterogeneity is significant during the period, however, as shown by the country dummies, which account for 41 per cent of the R-squared value. We interpret this result as reflecting heterogeneous country-specific supervisory policies and practices as well as banking system structures, not explicitly modelled in our framework. In fact, despite the financial integration process, there was hardly a common banking system structure or bank business model across the EA before the crisis, with a much higher share of investment banking and bank-assurance in some countries than in others, which were more focused on traditional commercial banking. These differences seem to have played a role in banks' choice to do business across borders, as also pointed out by the ECB (2012a) ${ }^{32}$.

\footnotetext{
${ }^{29}$ The regressions are estimated on quarterly data, with robust standard errors clustered at country $i$ level.

${ }^{30}$ Additional controls for proximity and common language have also been tested but they were not found to be significant in any of the three sub-periods considered. Results are therefore not reported for these additional controls.

31 Visco (2011) highlights that, "Formal statistical exercises also find a relatively weak correlation between spreads and fiscal fundamentals (i.e. the debt level, present and projected primary deficits) in the pre-crisis period. The correlation became stronger later, when it was already too late to avoid a major area-wide turmoil.”

${ }^{32}$ The degree of financial integration has not been even across banking sectors, with a higher integration of interbank activity and investment banking and a substantially lower integration in retail banking.
} 
- Global financial crisis: segmentation begins (column ii)

In the global financial crisis period, when segmentation begins, the focus switches to the variable accounting for common banking system conditions and to those controlling for portfolio allocation and external vulnerabilities, which are all significant in explaining the dynamics of banks' foreign claims. The common banking variable becomes significant and with the expected sign, reflecting the increased common riskiness in EA banks' conditions and its role in driving the decline in foreign claims. The portfolio allocation variables also become significant and with the expected sign in explaining the beginning of banks' retrenchment. In particular, the pull-back by lending banks is greater from those countries towards which their exposures are more concentrated. However, banks appear to be still selectively expanding their cross-border activity in those countries with favourable investment opportunities (i.e. higher interest rates) and sound fiscal conditions (i.e. lower debt-to-GDP), as shown by the positive and significant coefficient of Investment $_{i, j, t-1}$. External vulnerabilities also matter, as foreign banks pull back from the host countries that are more reliant on foreign banking, as shown by the negative sign of $\frac{F C_{j, t-1}}{\text { Asset }_{j, t-1}}$.

Finally, country specificities increase in weight during this period (with the country dummies explaining 54 per cent of the total R-squared), when factors such as purely domestic supervisory policies and country-specific banking system strategies are likely to have contributed substantially to banks' home bias, in the context of a mostly financial and banking crisis.

- Sovereign debt crisis: segmentation worsens (column iii)

Public finance, bank-sovereign link and flight-to-quality variables enter into play, as shown by their high significance, in the sub-period when sovereign tensions grow more acute in the Eurozone. Domestic bias is greater in banking systems headquartered in countries with weaker public finances (i.e. higher debt-to-GDP ratio) and with a tighter bank-sovereign link (i.e. larger increases in BETS). In this context of severe retrenchment and heightened sovereign tensions, banks also seek to reduce their risk exposures and search for safe investments - as shown by the significance of the flight-to-quality variable $F T Q_{i, j, t-1}$ - thus lending more to those countries with lower interest rates but also a lower debtto-GDP ratio.

The foreign claims portfolio concentration variable $\frac{F C_{i j, t-1}}{F C_{i, t-1}}$ and the external vulnerability variable $\frac{F C_{j, t-1}}{\text { Asset }_{j, t-1}}$ are almost as significant as in the previous crisis period, so that banks continue to retrench more from countries which represent a larger share of their portfolio of foreign claims and from those more reliant on foreign banking.

The role of country dummies diminishes during this period - contributing to explain 34 per cent of the R-squared and being lower compared with previous periods - while other variables in the model, and particularly those reflecting the worsening of public finance conditions and the tightening of the banksovereign link, better capture the systemic and sovereign dimension of this crisis period.

An additional result concerns the role of the form of banks' international organization in their domestic bias. Our finding confirms the intuition that it is easier for banks to pull back from a host country when 
operations are carried out directly from the bank’s home country (i.e. without any physical foreign settlement by means of branches and/or subsidiaries), confirming that fixed costs play a crucial role in the foreign activities of banks (Niepmann, 2013) and supporting the idea that deeper financial integration needs to be achieved through banks' foreign operations carried out with subsidiaries and branches. These are usually associated with retail and commercial banking rather than wholesale and interbank activity and hence entail a more direct involvement in the host country's fortunes and a less transitory presence.

\section{Table 4. Drivers of banks' foreign claims}

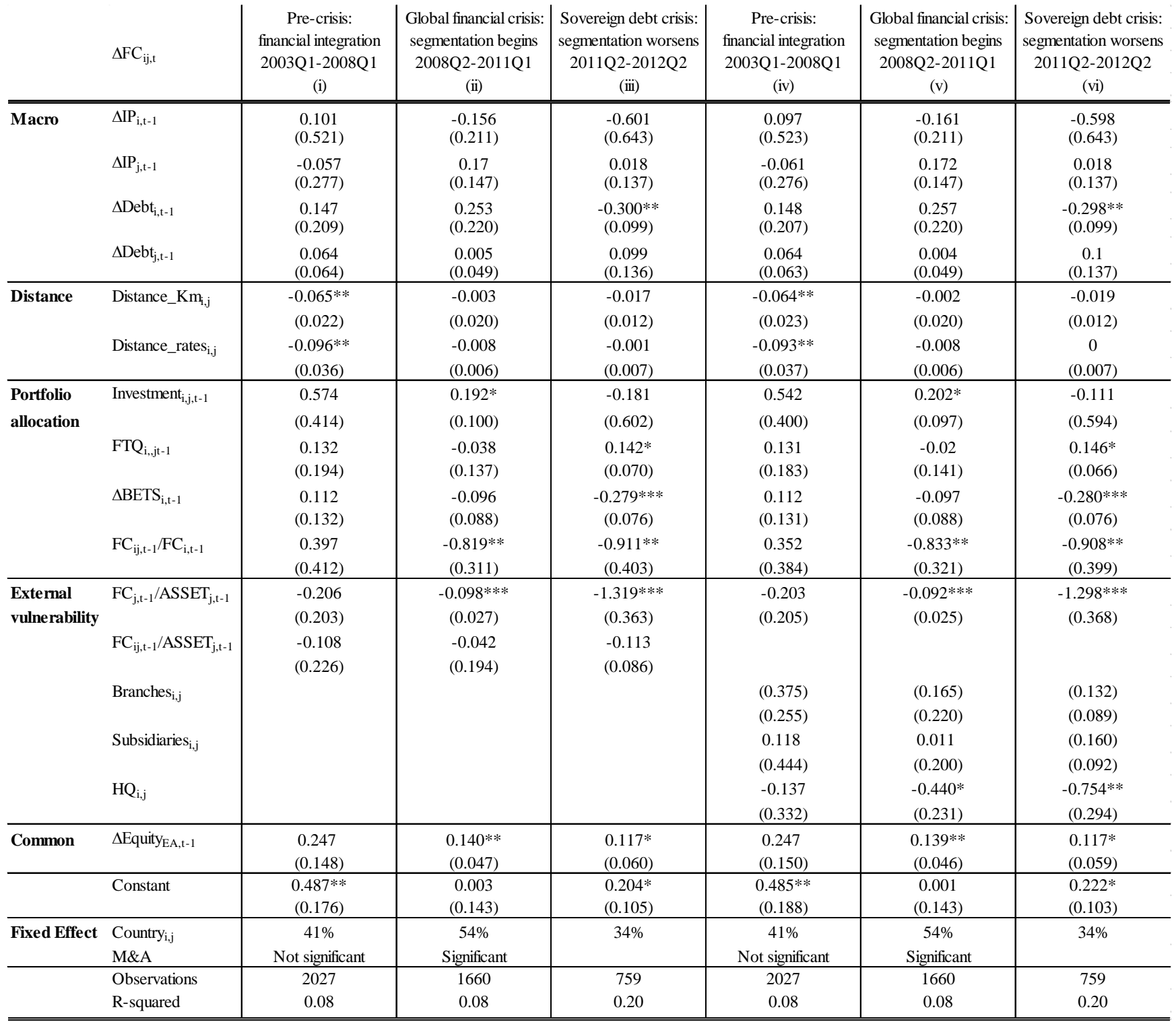

Clustered standard errors at the country level in parentheses; * significant at $10 \%$; ** significant at $5 \%$; *** significant at $1 \%$; dependent variable winsorized at the $1 \%$ and $99 \%$ levels and divided by 100 . For country dummies the percentage of explained R-squared is reported.

During the sovereign debt crisis the common equity variable continued to matter for bank choices about cross-border banking, albeit less so than in the previous period. This might indicate a decrease in the relevance of commonalities tout court for EA cross-border banking. However, in Table 5 we show that this is not the case. Rather, the nature of the commonalities changes over time as the nature of the 
crisis changes from financial to sovereign. Alongside the diminished importance of the variable for common banking sector conditions ( $\Delta E_{\text {Equity }}{ }_{E A, t-1}$ ) observed in Table 4 there is a corresponding higher significance of both variables used to capture commonalities in sovereign risks and the fear of a currency area break-up, namely the changes in the commonality of EA sovereign spreads

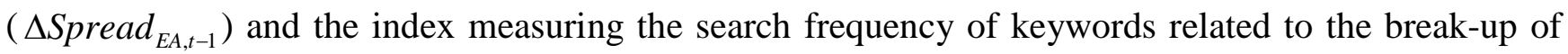
the EA $\left(\right.$ Google $\left._{E A, t-1}\right)$ as shown in Table 5. This confirms that during the sovereign debt crisis redenomination risk was the main common driver of EA banks' cross-border activity. To further confirm this result we test whether the decrease in the significance of the common banking variable $\Delta$ Equity $_{E A, t-1}$ in the last period could be due to a mis-specification of the variable itself rather than to a true change in the prevailing commonalities over time. We do so by using as an alternative common factor the changes in the implied volatility of the DAX index, as measured by the VDAX index, $\triangle V D A X_{E A, t-1}$. The results show that the significance of $\triangle V D A X_{E A, t-1}$ is comparable to that of

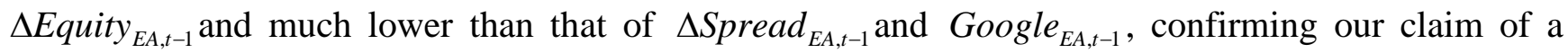
strong link between the decline of EA cross-border banking and an EA common factor capturing the redenomination risk. 


\section{Table 5. Drivers of banks’ bilateral foreign claims: testing for redenomination risk}

\begin{tabular}{|c|c|c|c|c|c|}
\hline & $\Delta \mathrm{FC}_{\mathrm{ij}, \mathrm{t}}$ & \multicolumn{4}{|c|}{$\begin{array}{c}\text { Sovereign debt crisis: } \\
\text { segmentation worsens } \\
\text { 2011Q2-2012Q2 }\end{array}$} \\
\hline \multirow[t]{4}{*}{ Macro } & $\Delta \mathrm{IP}_{\mathrm{i}, \mathrm{t}-1}$ & $\begin{array}{c}-0.662 \\
(0.560)\end{array}$ & $\begin{array}{l}-0.625 \\
(0.642)\end{array}$ & $\begin{array}{l}-0.598 \\
(0.643)\end{array}$ & $\begin{array}{c}-0.971 \\
(0.606)\end{array}$ \\
\hline & $\Delta \mathrm{IP}_{\mathrm{j}, \mathrm{t}-1}$ & $\begin{array}{l}-0.072 \\
(0.124)\end{array}$ & $\begin{array}{l}-0.052 \\
(0.136)\end{array}$ & $\begin{array}{c}0.018 \\
(0.137)\end{array}$ & $\begin{array}{l}-0.186 \\
(0.175)\end{array}$ \\
\hline & $\Delta \operatorname{Debt}_{\mathrm{i}, \mathrm{t}-1}$ & $\begin{array}{c}-0.261 * * \\
(0.099)\end{array}$ & $\begin{array}{c}-0.434 * * * \\
(0.117)\end{array}$ & $\begin{array}{c}-0.298 * * \\
(0.099)\end{array}$ & $\begin{array}{c}-0.312^{* *} \\
(0.104)\end{array}$ \\
\hline & $\Delta$ Debt $_{\mathrm{j}, \mathrm{t}-1}$ & $\begin{array}{c}0.054 \\
(0.144) \\
\end{array}$ & $\begin{array}{c}0.133 \\
(0.137) \\
\end{array}$ & $\begin{array}{c}0.1 \\
(0.137) \\
\end{array}$ & $\begin{array}{c}0.079 \\
(0.144) \\
\end{array}$ \\
\hline \multirow[t]{4}{*}{ Distance } & Distance_Km $\mathrm{K}_{\mathrm{i}, \mathrm{j}}$ & -0.016 & -0.021 & -0.019 & -0.017 \\
\hline & & $(0.012)$ & $(0.013)$ & $(0.012)$ & $(0.012)$ \\
\hline & Distance_rates $_{\mathrm{i}, \mathrm{j}}$ & -0.003 & 0.003 & 0 & -0.002 \\
\hline & & $(0.007)$ & $(0.007)$ & $(0.007)$ & $(0.007)$ \\
\hline \multirow[t]{8}{*}{ Ptf allocation } & Investment $_{\mathrm{i}, \mathrm{j}, \mathrm{t}-1}$ & -0.185 & -0.122 & -0.111 & -0.098 \\
\hline & & $(0.509)$ & $(0.637)$ & $(0.594)$ & $(0.459)$ \\
\hline & $\mathrm{FTQ}_{\mathrm{i}, \mathrm{jt}-1}$ & $0.154 * *$ & $0.132 *$ & $0.146^{*}$ & $0.152 * *$ \\
\hline & & $(0.067)$ & $(0.065)$ & $(0.066)$ & $(0.068)$ \\
\hline & $\Delta$ BETS $_{\mathrm{i}, \mathrm{t}-1}$ & $-0.305^{* * *}$ & $-0.123^{*}$ & $-0.280 * * *$ & $-0.263 * * *$ \\
\hline & & $(0.082)$ & $(0.058)$ & $(0.076)$ & $(0.063)$ \\
\hline & $\mathrm{FC}_{\mathrm{ij}, \mathrm{t}-1} / \mathrm{FC}_{\mathrm{i}, \mathrm{t}-1}$ & $-0.904 * *$ & $-0.903^{* *}$ & $-0.908 * *$ & $-0.904 * *$ \\
\hline & & $(0.397)$ & $(0.398)$ & $(0.399)$ & $(0.400)$ \\
\hline \multirow{8}{*}{$\begin{array}{l}\text { External } \\
\text { vulnerability }\end{array}$} & $\mathrm{FC}_{\mathrm{j}, \mathrm{t}-1} / \mathrm{ASSET}_{\mathrm{j}, \mathrm{t}-1}$ & $-1.099 * *$ & $-1.568 * * *$ & $-1.298 * * *$ & $-1.029 * *$ \\
\hline & & $(0.358)$ & $(0.438)$ & $(0.368)$ & $(0.359)$ \\
\hline & Branches $_{i, j}$ & $(0.129)$ & $(0.136)$ & $(0.132)$ & $(0.130)$ \\
\hline & & $(0.088)$ & $(0.093)$ & $(0.089)$ & $(0.087)$ \\
\hline & Subsidiaries $_{\mathrm{i}, \mathrm{j}}$ & $(0.146)$ & $-0.174 *$ & $(0.160)$ & $(0.150)$ \\
\hline & & $(0.092)$ & $(0.093)$ & $(0.092)$ & $(0.092)$ \\
\hline & $\mathrm{HQ}_{\mathrm{i}, \mathrm{j}}$ & $-0.721 * *$ & $-0.793 * *$ & $-0.754 * *$ & $-0.734 * *$ \\
\hline & & $(0.293)$ & $(0.284)$ & $(0.294)$ & $(0.289)$ \\
\hline \multirow[t]{4}{*}{ Common } & & $-0.367 * *$ & $-0.001 * * *$ & $0.117^{*}$ & $-0.067 *$ \\
\hline & & $(0.135)$ & 0.000 & $(0.059)$ & $(0.034)$ \\
\hline & Constant & $0.185^{*}$ & $0.271 * *$ & $0.222^{*}$ & $0.184^{*}$ \\
\hline & & $(0.098)$ & $(0.112)$ & $(0.103)$ & $(0.100)$ \\
\hline \multirow[t]{3}{*}{ Fixed Effect } & Country $_{\mathrm{i}, \mathrm{j}}$ & $32 \%$ & $29 \%$ & $35 \%$ & $34 \%$ \\
\hline & Observations & 759 & 759 & 759 & 759 \\
\hline & R-squared & 0.20 & 0.21 & 0.20 & 0.20 \\
\hline
\end{tabular}

Clustered standard errors at the country level in parentheses; * significant at $10 \%$; ** significant at 5\%; *** significant at $1 \%$; dependent variable winsorized at the $1 \%$ and $99 \%$ levels and divided by 100 . For country dummies the percentage of explained R-squared is reported.

\subsection{Robustness}

We carry out three robustness tests. The first concerns the interest rate used for the price based variables included in the model. We test the robustness of our results to the use of the retail deposit rate for the variables Distance_deposit_rates ${ }_{i, j}$, Investment ${ }_{i, j, t-1}$, and $F T Q_{i, j, t-1}$ by replacing it with a lending rate. ${ }^{33}$ Results, shown in Table 6, are consistent with those based on the deposit rate only for the $F T Q_{i, j, t-1}$ variable. This is not surprising as our preference for the deposit rates was not random, as

\footnotetext{
${ }^{33}$ We use the interest rates on new loans to households and non-financial corporations up to $€ 1$ million and with maturities up to 1 year.
} 
explained in Section 3.2. In fact, we did not expect to get fully consistent results using the loan rate which, unlike the deposit rate, could reflect mainly different levels of borrowers' credit risk across countries and so be unsuitable to pick up fundamental interest rate differentials due to factors other than credit risk.

Table 6. Drivers of banks’ bilateral foreign claims: testing for alternative interest rates

\begin{tabular}{|c|c|c|c|c|}
\hline & $\Delta \mathrm{FC}_{\mathrm{ij}, \mathrm{t}}$ & $\begin{array}{c}\text { Pre-crisis: } \\
\text { financial integration } \\
\text { 2003Q1-2008Q1 } \\
\text { (i) }\end{array}$ & $\begin{array}{c}\text { Global financial crisis: } \\
\text { segmentation begins } \\
\text { 2008Q2-2011Q1 } \\
\text { (ii) }\end{array}$ & $\begin{array}{l}\text { Sovereign debt crisis: } \\
\text { segmentation worsens } \\
\text { 2011Q2-2012Q2 } \\
\text { (iii) }\end{array}$ \\
\hline \multirow[t]{4}{*}{ Macro } & $\Delta \mathrm{IP}_{\mathrm{i}, \mathrm{t}-1}$ & $\begin{array}{c}0.086 \\
(0.525)\end{array}$ & $\begin{array}{l}-0.169 \\
(0.208)\end{array}$ & $\begin{array}{l}-0.601 \\
(0.646)\end{array}$ \\
\hline & $\Delta \mathrm{IP}_{\mathrm{j}, \mathrm{t}-1}$ & $\begin{array}{l}-0.063 \\
(0.278)\end{array}$ & $\begin{array}{c}0.156 \\
(0.149)\end{array}$ & $\begin{array}{c}0.008 \\
(0.143)\end{array}$ \\
\hline & $\Delta \operatorname{Debt}_{\mathrm{i}, \mathrm{t}-1}$ & $\begin{array}{c}0.159 \\
(0.210)\end{array}$ & $\begin{array}{c}0.253 \\
(0.218)\end{array}$ & $\begin{array}{c}-0.298 * * \\
(0.098)\end{array}$ \\
\hline & $\Delta \operatorname{Debt}_{\mathrm{j}, \mathrm{t}-1}$ & $\begin{array}{c}0.071 \\
(0.067) \\
\end{array}$ & $\begin{array}{c}0 \\
(0.049) \\
\end{array}$ & $\begin{array}{c}0.102 \\
(0.136) \\
\end{array}$ \\
\hline \multirow[t]{2}{*}{ Distance } & Distance_Km $\mathrm{K}_{\mathrm{i}, \mathrm{j}}$ & $\begin{array}{c}-0.063^{* *} \\
(0.024)\end{array}$ & $\begin{array}{l}-0.003 \\
(0.020)\end{array}$ & $\begin{array}{l}-0.021 \\
(0.013)\end{array}$ \\
\hline & Distance_rates $_{\mathrm{i}, \mathrm{j}}$ (LOAN) & $\begin{array}{l}-0.006 \\
(0.009) \\
\end{array}$ & $\begin{array}{c}0 \\
(0.005)\end{array}$ & $\begin{array}{c}0.002 \\
(0.003)\end{array}$ \\
\hline \multirow[t]{4}{*}{$\begin{array}{l}\text { Portfolio } \\
\text { allocation }\end{array}$} & Investment $_{\mathrm{i}, \mathrm{j}, \mathrm{t}-1 \text { (LOAN) }}$ & $\begin{array}{l}-0.452 \\
(0.291)\end{array}$ & $\begin{array}{c}0.04 \\
(0.099)\end{array}$ & $\begin{array}{c}0.046 \\
(0.108)\end{array}$ \\
\hline & $\mathrm{FTQ}_{\mathrm{i}, \mathrm{j}, \mathrm{t}-1 \text { (LOAN) }}$ & $\begin{array}{c}-0.1 \\
(0.537)\end{array}$ & $\begin{array}{l}-0.081 \\
(0.217)\end{array}$ & $\begin{array}{c}0.139 * * \\
(0.047)\end{array}$ \\
\hline & $\Delta$ BETS $_{\mathrm{i}, \mathrm{t}-1}$ & $\begin{array}{c}0.106 \\
(0.130)\end{array}$ & $\begin{array}{l}-0.101 \\
(0.087)\end{array}$ & $\begin{array}{c}-0.280^{* * *} \\
(0.077)\end{array}$ \\
\hline & $\mathrm{FC}_{\mathrm{ij}, \mathrm{t}-1} / \mathrm{FC}_{\mathrm{i}, \mathrm{t}-1}$ & $\begin{array}{c}0.351 \\
(0.370) \\
\end{array}$ & $\begin{array}{c}-0.822^{* *} \\
(0.328) \\
\end{array}$ & $\begin{array}{c}-0.898^{* *} \\
(0.402) \\
\end{array}$ \\
\hline \multirow[t]{4}{*}{$\begin{array}{l}\text { External } \\
\text { vulnerability }\end{array}$} & $\mathrm{FC}_{\mathrm{j}, \mathrm{t}-1} / \mathrm{ASSET}_{\mathrm{j}, \mathrm{t}-1}$ & $\begin{array}{l}-0.185 \\
(0.198)\end{array}$ & $\begin{array}{c}-0.083^{* * *} \\
(0.024)\end{array}$ & $\begin{array}{c}-1.287^{* * *} \\
(0.350)\end{array}$ \\
\hline & Branches $_{\mathrm{i}, \mathrm{j}}$ & $\begin{array}{l}(0.365) \\
(0.248)\end{array}$ & $\begin{array}{l}(0.167) \\
(0.238)\end{array}$ & $\begin{array}{l}(0.131) \\
(0.093)\end{array}$ \\
\hline & Subsidiaries $_{\mathrm{i}, \mathrm{j}}$ & $\begin{array}{l}0.136 \\
(0.438)\end{array}$ & $\begin{array}{l}0.002 \\
(0.206)\end{array}$ & $\begin{array}{l}(0.170) \\
(0.103)\end{array}$ \\
\hline & $\mathrm{HQ}_{\mathrm{i}, \mathrm{j}}$ & $\begin{array}{l}-0.125 \\
(0.343) \\
\end{array}$ & $\begin{array}{l}-0.446^{*} \\
(0.234) \\
\end{array}$ & $\begin{array}{c}-0.765^{* *} \\
(0.302) \\
\end{array}$ \\
\hline \multirow[t]{2}{*}{ Common } & $\Delta$ Equity $_{\mathrm{EA}, \mathrm{t}-1}$ & $\begin{array}{c}0.239 \\
(0.144) \\
\end{array}$ & $\begin{array}{c}0.134^{* *} \\
(0.050) \\
\end{array}$ & $\begin{array}{l}0.115^{*} \\
(0.060) \\
\end{array}$ \\
\hline & Constant & $\begin{array}{c}0.460^{* *} \\
(0.191) \\
\end{array}$ & $\begin{array}{c}0.017 \\
(0.117) \\
\end{array}$ & $\begin{array}{l}0.238^{*} \\
(0.109) \\
\end{array}$ \\
\hline \multirow[t]{2}{*}{ Fixed Effect } & $\begin{array}{l}\text { Country }_{\mathrm{i}, \mathrm{j}} \\
\text { M\&A }\end{array}$ & $\begin{array}{c}39 \% \\
\text { Not significant } \\
\end{array}$ & $\begin{array}{c}53 \% \\
\text { Significant } \\
\end{array}$ & $35 \%$ \\
\hline & $\begin{array}{l}\text { Observations } \\
\text { R-squared }\end{array}$ & $\begin{array}{l}2027 \\
0.08\end{array}$ & $\begin{array}{l}1660 \\
0.08\end{array}$ & $\begin{array}{l}759 \\
0.20\end{array}$ \\
\hline
\end{tabular}

In the second robustness check we test our choice of estimating the model separately for the three subperiods considered. We do so by estimating a pooled model for the entire period from 2003Q1 to 2012Q2, with time-invariant home and host country fixed effects and with all the other variables interacted with time dummies for each of the three sub-periods. The results, presented in Table 7 , are consistent with those shown in Table 4. They also validate our main choice of estimating the model 
separately for the three sub-periods, as the percentage of the R-squared explained by the country fixed effects is much lower when they are time-invariant in the pooled framework, albeit without any significant change in the overall explanatory power of the model (Table 7), than when they are allowed to change across the three sub-periods (Table 4).

Table 7. Drivers of banks' bilateral foreign claims: testing for constant country fixed effects

\begin{tabular}{|c|c|c|c|c|}
\hline & $\Delta \mathrm{FC}_{\mathrm{ij}, \mathrm{t}}$ & $\begin{array}{c}\text { Pre-crisis: } \\
\text { financial integration } \\
\text { 2003Q1-2008Q1 } \\
\text { (i) }\end{array}$ & $\begin{array}{l}\text { Global financial crisis: } \\
\text { segmentation begins } \\
\text { 2008Q2-2011Q1 } \\
\text { (ii) }\end{array}$ & \begin{tabular}{|} 
Sovereign debt crisis: \\
segmentation worsens \\
2011Q2-2012Q2 \\
(iii)
\end{tabular} \\
\hline \multirow[t]{4}{*}{ Macro } & $\Delta \mathrm{IP}_{\mathrm{i}, \mathrm{t}-1}$ & $\begin{array}{c}0.445 \\
(0.553)\end{array}$ & $\begin{array}{l}-0.209 \\
(0.226)\end{array}$ & $\begin{array}{l}-1.110^{*} \\
(0.546)\end{array}$ \\
\hline & $\Delta \mathrm{IP}_{\mathrm{j}, \mathrm{t}-1}$ & $\begin{array}{l}-0.064 \\
(0.325)\end{array}$ & $\begin{array}{c}0.217 \\
(0.140)\end{array}$ & $\begin{array}{l}-0.129 \\
(0.226)\end{array}$ \\
\hline & $\Delta \operatorname{Debt}_{\mathrm{i}, \mathrm{t}-1}$ & $\begin{array}{c}0.054 \\
(0.204)\end{array}$ & $\begin{array}{c}0.255 \\
(0.166)\end{array}$ & $\begin{array}{c}-0.424 * * * \\
(0.078)\end{array}$ \\
\hline & $\Delta$ Debt $_{\mathrm{j}, \mathrm{t}-1}$ & $\begin{array}{c}0.025 \\
(0.065) \\
\end{array}$ & $\begin{array}{l}-0.014 \\
(0.068) \\
\end{array}$ & $\begin{array}{l}-0.075 \\
(0.122) \\
\end{array}$ \\
\hline \multirow[t]{2}{*}{ Distance } & Distance_Km $\mathrm{K}_{\mathrm{i}, \mathrm{j}}$ & $\begin{array}{c}-0.034^{* * *} \\
(0.008)\end{array}$ & $\begin{array}{c}-0.033^{* * *} \\
(0.008)\end{array}$ & $\begin{array}{c}-0.034 * * * \\
(0.009)\end{array}$ \\
\hline & Distance_rates $_{\mathrm{i}, \mathrm{j}}$ & $\begin{array}{c}-0.053 * * \\
(0.017)\end{array}$ & $\begin{array}{l}-0.009 \\
(0.005)\end{array}$ & $\begin{array}{c}0.002 \\
(0.005)\end{array}$ \\
\hline \multirow[t]{4}{*}{$\begin{array}{l}\text { Portfolio } \\
\text { allocation }\end{array}$} & Investment $_{\mathrm{i}, \mathrm{j}, \mathrm{t}-1}$ & $\begin{array}{l}-0.225 \\
(0.302)\end{array}$ & $\begin{array}{l}-0.033 \\
(0.108)\end{array}$ & $\begin{array}{l}-0.551 \\
(0.381)\end{array}$ \\
\hline & $\mathrm{FTQ}_{\mathrm{i}, \mathrm{jt}-1}$ & $\begin{array}{c}0.002 \\
(0.268)\end{array}$ & $\begin{array}{c}0.298 \\
(0.182)\end{array}$ & $\begin{array}{c}0.255^{* * *} \\
(0.047)\end{array}$ \\
\hline & $\Delta$ BETS $_{\mathrm{i}, \mathrm{t}-1}$ & $\begin{array}{c}0.06 \\
(0.120)\end{array}$ & $\begin{array}{c}0.024 \\
(0.100)\end{array}$ & $\begin{array}{c}-0.215^{* *} \\
(0.083)\end{array}$ \\
\hline & $\mathrm{FC}_{\mathrm{ij}, \mathrm{t}-1} / \mathrm{FC}_{\mathrm{i}, \mathrm{t}-1}$ & $\begin{array}{c}0.741 \\
(0.517) \\
\end{array}$ & $\begin{array}{c}-0.934^{* *} \\
(0.406) \\
\end{array}$ & $\begin{array}{c}-1.108^{* *} \\
(0.387) \\
\end{array}$ \\
\hline \multirow[t]{4}{*}{$\begin{array}{l}\text { External } \\
\text { vulnerability }\end{array}$} & $\mathrm{FC}_{\mathrm{j}, \mathrm{t}-1} / \mathrm{ASSET}_{\mathrm{j}, \mathrm{t}-1}$ & $\begin{array}{c}0.014 \\
(0.073)\end{array}$ & $\begin{array}{c}-0.067^{* * *} \\
(0.016)\end{array}$ & $\begin{array}{c}0.019 \\
(0.032)\end{array}$ \\
\hline & Branches $_{\mathrm{i}, \mathrm{j}}$ & $\begin{array}{l}(0.226) \\
(0.335)\end{array}$ & $\begin{array}{l}(0.314) \\
(0.256)\end{array}$ & $\begin{array}{l}-0.279^{*} \\
(0.154)\end{array}$ \\
\hline & Subsidiaries $_{\mathrm{i}, \mathrm{j}}$ & $\begin{array}{c}0.231 \\
(0.373)\end{array}$ & $\begin{array}{l}(0.125) \\
(0.227)\end{array}$ & $\begin{array}{l}-0.199 * \\
(0.100)\end{array}$ \\
\hline & $\mathrm{HQ}_{\mathrm{i}, \mathrm{j}}$ & $\begin{array}{l}-0.133 \\
(0.481)\end{array}$ & $\begin{array}{l}-0.398 \\
(0.236)\end{array}$ & $\begin{array}{c}-0.641 * * \\
(0.253)\end{array}$ \\
\hline \multirow[t]{2}{*}{ Common } & $\Delta$ Equity $_{\mathrm{EA}, \mathrm{t}-1}$ & $\begin{array}{l}0.290 * \\
(0.146)\end{array}$ & $\begin{array}{c}0.111 * * \\
(0.039)\end{array}$ & $\begin{array}{c}0.041 \\
(0.062)\end{array}$ \\
\hline & Constant & & $\begin{array}{c}0.207 * * * \\
(0.060)\end{array}$ & \\
\hline \multirow[t]{2}{*}{ Fixed Effect } & $\begin{array}{l}\text { Country } y_{i, j} \\
\text { M\&A }\end{array}$ & & $\begin{array}{c}13 \% \\
\text { Not significant }\end{array}$ & \\
\hline & $\begin{array}{l}\text { Observations } \\
\text { R-squared }\end{array}$ & & $\begin{array}{l}4446 \\
0.08\end{array}$ & \\
\hline
\end{tabular}

Clustered standard errors at the country level in parentheses; * significant at $10 \%$; ** significant at $5 \%$; *** significant at $1 \%$; dependent variable winsorized at the $1 \%$ and $99 \%$ levels and divided by 100 . For country dummies the percentage of explained R-squared is reported.

As a third check we test the robustness of the estimates to a potential inconsistency in the definition of our dependent variable $\Delta F C_{i, j, t}$, for which we use consolidated data for the numerator (i.e. foreign claims of a given banking group are attributed to the country where the group is headquartered) and locational data for the denominator (i.e. assets are attributed to a given country based on the residence of the single bank and not that of the group it belongs to). This choice is due to a lack of adequate 
consolidated banking system data for the EA countries with a frequency and a time span consistent with those of foreign claims. We explore whether it could have affected the robustness of the estimates by re-estimating our model using the available consolidated banking system assets as the denominator of $\Delta F C_{i, j, t}$. In practice, no consolidated banking system data is available for the financial integration sub-period, so we are only able to estimate the model for the global financial crisis and the sovereign debt crisis sub-periods for which we have data. However, these are not available at all times for all the EA countries considered and their frequency - annual or semi-annual at best - is much lower than that of the numerator (quarterly). Despite all these data shortcomings, the results shown in Table 8 remain largely consistent with those presented in Table 4, confirming that the non-full homogeneity of the data entering our dependent variable is of very limited relevance. 
Table 8. Drivers of banks' bilateral foreign claims: alternative definition of the dependent variable

\begin{tabular}{|c|c|c|c|}
\hline & $\Delta \mathrm{FC}_{\mathrm{ij}, \mathrm{t}}($ CONSOLIDATED) & $\begin{array}{l}\text { Global financial crisis: } \\
\text { segmentation begins } \\
\text { 2008Q2-2011Q1 } \\
\text { (i) }\end{array}$ & $\begin{array}{l}\text { Sovereign debt crisis: } \\
\text { segmentation worsens } \\
\text { 2011Q2-2012Q2 } \\
\text { (ii) }\end{array}$ \\
\hline \multirow[t]{4}{*}{ Macro } & $\Delta \mathrm{IP}_{\mathrm{i}, \mathrm{t}-1}$ & $\begin{array}{l}-0.013 \\
(0.293)\end{array}$ & $\begin{array}{l}-0.637 \\
(0.576)\end{array}$ \\
\hline & $\Delta \mathrm{IP}_{\mathrm{j}, \mathrm{t}-1}$ & $\begin{array}{c}0.163 \\
(0.178)\end{array}$ & $\begin{array}{l}-0.173 \\
(0.130)\end{array}$ \\
\hline & $\Delta \operatorname{Debt}_{\mathrm{i}, \mathrm{t}-1}$ & $\begin{array}{c}0.248 \\
(0.301)\end{array}$ & $\begin{array}{c}-0.228 * * \\
(0.101)\end{array}$ \\
\hline & $\Delta \operatorname{Debt}_{\mathrm{j}, \mathrm{t}-1}$ & $\begin{array}{c}0.026 \\
(0.058) \\
\end{array}$ & $\begin{array}{c}0.02 \\
(0.059) \\
\end{array}$ \\
\hline \multirow[t]{2}{*}{ Distance } & Distance_Km $\mathrm{i}_{\mathrm{i}, \mathrm{j}}$ & $\begin{array}{c}0.01 \\
(0.017)\end{array}$ & $\begin{array}{l}-0.014 \\
(0.010)\end{array}$ \\
\hline & Distance_rates $\mathrm{i}_{\mathrm{i}, \mathrm{j}}$ & $\begin{array}{l}-0.008 \\
(0.006)\end{array}$ & $\begin{array}{l}-0.002 \\
(0.008)\end{array}$ \\
\hline \multirow[t]{4}{*}{$\begin{array}{l}\text { Portfolio } \\
\text { allocation }\end{array}$} & Investment $_{\mathrm{i}, \mathrm{j}, \mathrm{t}-1}$ & $\begin{array}{c}0.165 \\
(0.095)\end{array}$ & $\begin{array}{c}0.184 \\
(0.580)\end{array}$ \\
\hline & $\mathrm{FTQ}_{\mathrm{i}, \mathrm{jt}-1}$ & $\begin{array}{l}-0.113 \\
(0.140)\end{array}$ & $\begin{array}{c}0.035 \\
(0.062)\end{array}$ \\
\hline & $\Delta$ BETS $_{\mathrm{i}, \mathrm{t}-1}$ & $\begin{array}{l}-0.057 \\
(0.078)\end{array}$ & $\begin{array}{c}-0.326^{* * *} \\
(0.067)\end{array}$ \\
\hline & $\mathrm{FC}_{\mathrm{ij}, \mathrm{t}-1} / \mathrm{FC}_{\mathrm{i}, \mathrm{t}-1}$ & $\begin{array}{c}-0.779 * * * \\
(0.211)\end{array}$ & $\begin{array}{c}-1.235 * * * \\
(0.350)\end{array}$ \\
\hline \multirow[t]{4}{*}{$\begin{array}{l}\text { External } \\
\text { vulnerability }\end{array}$} & $\mathrm{FC}_{\mathrm{j}, \mathrm{t}-1} / \mathrm{ASSET}_{\mathrm{j}, \mathrm{t}-1}$ & $\begin{array}{c}-0.091^{* *} \\
(0.031)\end{array}$ & $\begin{array}{c}-1.433^{* * *} \\
(0.248)\end{array}$ \\
\hline & Branches $_{i, j}$ & $\begin{array}{l}0.112 \\
(0.162)\end{array}$ & $\begin{array}{l}(0.090) \\
(0.093)\end{array}$ \\
\hline & Subsidiaries $_{\mathrm{i}, \mathrm{j}}$ & $\begin{array}{l}0.115 \\
(0.115)\end{array}$ & $\begin{array}{l}(0.081) \\
(0.078)\end{array}$ \\
\hline & $\mathrm{HQ}_{\mathrm{i}, \mathrm{j}}$ & $\begin{array}{l}-0.392 * \\
(0.185)\end{array}$ & $\begin{array}{c}-0.727^{* *} \\
(0.286)\end{array}$ \\
\hline \multirow[t]{2}{*}{ Common } & $\Delta$ Equity $_{\mathrm{EA}, \mathrm{t}-1}$ & $\begin{array}{c}0.188 * * * \\
(0.054) \\
\end{array}$ & $\begin{array}{c}0.111 \\
(0.072) \\
\end{array}$ \\
\hline & Constant & $\begin{array}{l}-0.157 \\
(0.121) \\
\end{array}$ & $\begin{array}{l}0.187^{*} \\
(0.089)\end{array}$ \\
\hline \multirow[t]{2}{*}{ Fixed Effect } & $\begin{array}{l}\text { Country }_{\mathrm{i}, \mathrm{j}} \\
\text { M\&A }\end{array}$ & $\begin{array}{c}40 \% \\
\text { Not significant }\end{array}$ & $36 \%$ \\
\hline & $\begin{array}{l}\text { Observations } \\
\text { R-squared }\end{array}$ & $\begin{array}{l}1418 \\
0.11\end{array}$ & $\begin{array}{c}759 \\
0.30\end{array}$ \\
\hline
\end{tabular}

Clustered standard errors at the country level in parentheses; * significant at $10 \%$; ** significant at $5 \%$; ${ }^{* * *}$ significant at $1 \%$; dependent variable winsorized at the $1 \%$ and $99 \%$ levels and divided by 100 . For country dummies the percentage of explained Rsquared is reported.

\section{Conclusions}

In this paper we present stylized facts of the segmentation of cross-border banking within the EA and study the phenomenon to shed light on the main drivers of banks' retrenchment within the domestic borders. We also analyse whether the evolution of cross-border banking changed over-time and find that this is in fact the case. In the period before the global financial crisis the physical and financial distances between countries were the main drivers of cross-border banking. Then, when the crisis struck, the focus shifted to EA banking system conditions: the lending banks sought to reduce the concentration of their foreign claims portfolio and their exposures towards the countries with the 
greatest external vulnerability but they retrenched less from those countries which were still profitable investment opportunities and had a sound fiscal position. As sovereign tensions grew more acute, while banks continued to reduce the concentration of their foreign claims portfolio and their exposures towards the countries with the greatest external vulnerability, the focus shifted again to the sovereign conditions and the bank-sovereign link. We also find that the form of banks' international organization matters for banks' retrenchment, making it easier for banks' to pull back from a host country when operations are carried out without foreign branches and/or subsidiaries.

EA common factors, rather than just country-specific determinants, are very relevant in explaining the decline of cross-border banking and the resulting segmentation of the EA banking system. The nature of the common factors changed during the crisis, however: in particular, we show that during the global crisis commonalities in banks' conditions were particularly significant whereas during the sovereign debt crisis redenomination risk was an important common factor for banks' home bias.

Throughout the three sub-periods country dummies are steadily significant. We interpret this evidence as reflecting two main factors not otherwise explicitly modelled: the country-specific banking system structures and strategies, as well as the heterogeneity in EA countries' supervisory policies and practices, including in the form of ring-fencing policies.

One of the key problems in Europe has been the perverse feedback loop between sovereign risk, fragile banking systems and weak economic growth. The loop has proven extremely hard to break and the trend towards financial system balkanization has been part of this loop. The ECB's accommodative monetary policy stance and its unconventional measures have been a key turning point in the stabilization of the EA financial system. Enduring financial stability is yet to be achieved, however. Restoring a truly unified financial market is fundamental for this purpose as it will also help to restore an effective single monetary policy and adequate credit flows across the region.

A number of initiatives are likely to contribute to re-start financial re-integration in the EA: i) implementing the Single Supervisory Mechanism ${ }^{34}$ will help to reduce cross-country heterogeneities in banks' soundness and make the level of cross-border banking services in Europe less dependent on the geographical location of banks' headquarters; ${ }^{35}$ ii) implementing a common resolution and deposit insurance framework and recognizing sovereign risks in banks' portfolios will help to break the vicious bank-sovereign link; iii) fostering a larger share of cross-border banking carried out through branches and subsidiaries would make the foreign presence of banks less volatile and EA financial integration deeper; and iv) sounder fiscal positions in countries would provide incentives to restore stable crossborder flows.

A full recovery from the profound segmentation of the EA banking system will inevitably require time; but to be long-lasting it will need to be grounded in bold policies, ultimately aimed at further strengthening the European Union beyond the financial sphere.

\footnotetext{
${ }^{34}$ Barba Navaretti et al. (2010) find complementarities between economic integration and multinational banks' internal capital markets in Europe supporting the call for an integration of the European supervisory and regulatory framework overseeing multinational banks.
} 


\section{References}

Allen, F., Beck, T., Carletti, E., Lane, P.R., Schoenmaker, D. and Wagner, W. (2011), Cross-Border Banking in Europe: Implications for Financial Stability and Macroeconomic Policies, Centre for Economic Policy Research (CEPR): London

Angelini, P., Nicoletti-Altimari, S. and Visco, I. (2013), 'Macroprudential, microprudential and monetary policies: conflicts, complementarities and trade-offs', in Dombret, A. and Lucius, O. (eds.), Stability of the Financial System - Illusion or Feasible Concept?, Edward Elgar Publishing

Banca d'Italia (2012), Financial Stability Report, No. 4, November

Bank for International Settlements (2012), 'Detailed tables on preliminary locational and consolidated banking statistics at end-June 2012', October, Table 9, http://www.bis.org/statistics/consstats.htm

Barba Navaretti, G., Calzolari, G., Pozzolo, A.F. and Levi, M. (2010), 'Multinational Banking in Europe - Financial Stability and Regulatory Implications: Lessons from the Financial Crisis’, Development Working Papers, 292, Centro Studi Luca d’Agliano, Università degli Studi di Milano, April

Bologna, P. (2013), 'Structural Funding and Bank Failures - Does Basel 3 Net Stable Funding Ratio Target the Right Problem?', Journal of Financial Services Research, 10.1007/s10693-0130180-4

Bruno, V. and Shin, H.S. (2013), ‘Capital Flows, Cross-Border Banking and Global Liquidity’. NBER Working Paper, No. 19038

Buch, C.M. (2003), 'Information or Regulation: What Drives the International Activities of Commercial Banks?’, Journal of Money, Credit and Banking, 35(6), 851-869

Buch, C.M., Driscoll, J.C. and Ostergaard, C. (2010), 'Cross-Border Diversification in Bank Asset Portfolios', International Finance, 13(1), 79-108

Cerutti, E., Ilyna, A., Makarova, Y. and Schmieder, C. (2010), 'Bankers Without Borders? Implications of Ring-Fencing for European Cross-Border Banks’, IMF Working Paper, WP/10/247

Cerutti, E., Dell’Ariccia, G. and Martínez Pería, M.S. (2007), 'How do banks go abroad: Branches or subsidiaries?', Journal of Banking and Finance, 31(6), 1669-1692

Dell'Ariccia, G. and Marquez, R. (2010), 'Risk and the Corporate Structure of Banks', Journal of Finance, 65(3), 1075-1096

Draghi, M. and Constâncio, V. (2013), 'Introductory statement to the press conference’. Frankfurt am Main, 7 February

European Central Bank (2012a), Financial Integration in Europe. April 
European Central Bank (2012b), 'Technical features of Outright Monetary Transactions', Press Release, September 6

Fiechter, J., Ötker-Robe, İ., Ilyina, A., Hsu, M., Santos, A. and Surti, J. (2011), 'Subsidiaries or Branches: Does One Size Fit All?’, IMF Staff Discussion Note, SND/11/04

García Herrero, A. and Martínez Pería, M.S. (2007), ‘The mix of international banks’ foreign claims: Determinants and implications', Journal of Banking and Finance, 31, 1613-1631

Hermann, S. and Mihaljek, D. (2013), 'The determinants of cross-border bank flows to emerging markets - New empirical evidence on the spread of the financial crises', Economics of Transition, 21(3), 479-508

International Monetary Fund (2012), 'Euro Area policies, 2012 Article IV Consultation’, IMF Country Report No.12/181, July

Kruszka, M. and Kowalczyk, M. (2011), 'Macro-Prudential Regulation of Credit Booms and Busts The Case of Poland', World Bank Policy Research Working Paper, WPS5832

Laeven, L. and Tressel, T. (2013), 'Financial Integration and Fragmentation in the European Union. International Monetary Fund Technical Note’, IMF Country Report No. 13/71, March

Lane, P.R. and Milesi-Ferretti, G.M. (2008), 'International Investment Patterns', The Review of Economics and Statistics, 90(3), 538-549

Lee, E.S. (1966), A Theory of Migration, University of Pennsylvania

Manna, M. (2011), 'Home bias in interbank lending and banks' resolution regimes', Banca d'Italia, Temi di discussion (Working Papers), No. 816

Morgan Stanley (2012), ‘The State of Dis-Union: Balkanisation \& Banking Union’, Industry View, June 26

Niepmann, F. (2013), 'Banking across Borders with Heterogeneous Banks', Federal Reserve Bank of New York Staff Reports, No. 609

Okawa, Y. and van Wincoop, E. (2012), 'Gravity in International Finance', Journal of International Economics, 87(2), 205-215

Pianeselli, D. and Zaghini, A. (2013), 'The Cost of Firms' Debt Financing', CFS Working Paper Series, No. 2013/03

Portes, R. and Rey, H. (2005), 'The determinants of cross-border equity flows', Journal of International Economics, 65(2), 269-296

Sgherri, S. (2012), 'Commonalities, Mispricing, and Spillovers: Another Look at Euro Area Sovereign Risk', in International Monetary Fund, 2012 Spillover Report - Background Papers, July 10 
Sgherri, S. and Zoli, E. (2009), 'Euro Area Sovereign Risk During the Crisis', IMF Working Paper, WP/09/222

Stock, J.H. and Yogo, M. (2005), Testing for Weak Instruments in Linear IV Regression in Identification and Inference for Econometric Models: Essays in Honor of Thomas Rothenberg, Available at SSRN: http://ssrn.com/abstract=1734933

Tinbergen, J. (1962), Shaping the World Economy: Suggestions for an International Economic Policy, New York: Twentieth Century Fund.

Turner, A. (2009), Turner Review Press Conference, 18 March

Visco, I. (2011), 'Rethinking economic policy in Europe - A new era of EU economic governance', Speech at the Brussels Economic Forum 2011 "Rethinking Economic Policy in Europe - A New Era of EU Economic Governance", 18 May, http://ec.europa.eu/economy_finance/bef2011/programme-speeches/index.html 